\title{
Methane seepage effects on biodiversity and biological traits of macrofauna inhabiting authigenic carbonates
}

\author{
Lisa A. Levin*, Guillermo F. Mendoza, Benjamin M. Grupe ${ }^{1}$ \\ Scripps Institution of Oceanography, La Jolla CA, 92093-0218, USA
}

1. Current Address: Fisheries and Oceans Canada, Institute of Ocean Sciences, 9860 West Saanich Road, Sidney BC V8L 4B2, Canada

\begin{abstract}
.
Authigenic carbonate rocks at methane seeps are recognized as hosting diverse and abundant invertebrate assemblages, with potential forcing from fluid seepage and hydrography. Mensurative studies of carbonate macrofauna $(>0.3 \mathrm{~mm}$ ) at Hydrate Ridge, OR revealed little effect of water depth and overlying oxygenation (at $600 \mathrm{~m}$ and $800 \mathrm{~m}$ ) but a large influence of seepage activity on density, taxonomic composition, diversity, and biological traits (feeding, lifestyle, motility, size and calcification). Rocks exposed to active seepage had 3-4 x higher total macrofaunal densities than under inactive conditions. Assemblages exhibited higher species richness and reduced evenness (greater dominance) under active seepage than inactive conditions, but no difference in $\mathrm{H}^{\prime}$ or $\mathrm{J}^{\prime}$. Actively seeping sites were characterized by errant (motile), bacterial grazing, small- and medium-sized, heavily calcified species, whereas inactive sites exhibited a greater diversity of feeding modes and more burrowers, sessile, large and lightly calcified species. Active rocks supported more exogonid (Syllidae), ampharetid, and cirratulid polychaetes, provannid snails, pyropeltid limpets, nemerteans, and sponges; whereas inactive rocks supported higher densities of ophiuroids, isopods, gammarid amphipods, hydroids, Typosyllis (Syllidae) and tanaids. Transplant experiments, in which rocks were transferred between active and inactive sites at Hydrate Ridge North $(600 \mathrm{~m})$, revealed that assemblages respond within 13 mo to increases or cessation of seepage, taking on the feeding, size and calcification characteristics of the background fauna at the new site. Lifestyles and motility patterns shifted more slowly as the sessile, attached species did not track seepage as quickly. Provannid snails and pyropeltid limpets rapidly colonized rocks transplanted to active sites and disappeared when transplanted to inactive sites. Given the known variability of fluid fluxes and rapid community response, a mosaic of communities changing in space and time is hypothesized to generate the relatively high species diversity at methane seeps.
\end{abstract}

Key words: biodiversity, biological trait analysis, carbonate, deep sea, macrofauna, methane seep, oxygen, Hydrate Ridge

*corresponding author: llevin@ucsd.edu 


\section{Introduction.}

The ocean's continental margins hold vast repositories of buried methane which escapes upward to the seafloor, fueling methane seep ecosystems reliant on chemosynthetic microbial activity (Levin, 2005). Where this occurs sulfate-coupled anaerobic methane oxidation (AOM) is catalyzed by syntrophic methanotrophic archaea (ANME) and sulfurmetabolizing deltaproteobacteria (SRB) (Boetius et al., 2000). This process can significantly shape the seep landscape, through the authigenic precipitation of carbonate rock. Carbonate features include extensive pavements, mounds, slabs, boulders and nodules (Aloisi et al., 2002) that persist for extended periods at sites with active and past seepage (e.g., Peckmann \& Thiel, 2004; Birgel et al., 2008; Birgel \& Peckmann, 2008; Shapiro, 2004). Massive AOM-based carbonate formations are well described in the eastern Pacific Ocean from the margins of Alaska (Gieskes et al., 2005), Oregon (Bohrmann et al. 1998), California (Stakes et al., 1999), Costa Rica (Han et al., 2004) and Chile (Sellanes et al., 2004). Carbonates form extensive habitat in the Black Sea (Reitner et al., 2005; Bahr et al., 2009), the eastern Mediterranean Sea (Heijs et al., 2006), off W. Africa (Menot et al., 2010), and at most W. Atlantic seeps (Van Dover et al., 2003).

Seep carbonates have recently been shown to serve as a unique habitat and an important methane sink, by hosting active methane-oxidizing ANME-SRB microbial consortia (Marlow et al., 2014a,b). Molecular analyses of the microbial diversity associated with carbonates from active seepage areas at Hydrate Ridge OR reveal archaeal and bacterial 16S rRNA phylotypes that are broadly similar to the assemblages recovered from seep sediments (Marlow et al., 2014a). However, there is a distinction in community structure in carbonates from active seepage areas compared to those from quiescent, off seep locations (Marlow et al., 2014a). The discovery of viable methane-oxidizing ANME-SRB consortia within the interior of seep carbonates (Marlow et al., 2014b), introduces questions about the use of carbonates as a habitat and food source by metazoans.

It is only recently that the eukaryote macrofaunal communities associated with seep carbonates have been described (Gaudron et al., 2010; Ritt et al., 2011; Grupe et al., 2015; Levin et al., 2015). Common faunal associations with carbonates include loosely associated mobile megafauna, attached epifauna, and endolithofauna (those that live in burrows, crevices and mineral lattices within the rock). The rocks may provide substrate for settlement and attachment, reproductive sites, refuge from predators and, in many cases, a food supply. Limited study of carbonate-hosted macrofauna in the Mediterranean (Ritt et al., 2010; Gaudron et al., 2010) and Atlantic (Cunha et al., 2013) suggests that faunal densities may be low and heterogeneity high compared to seep sediments. Grupe et al. (2015) and Levin et al. (2015) document abundant macrofauna on carbonates from the Del Mar Seep, CA and Costa Rica seeps, respectively. However faunal communities on carbonates appear more likely to resemble seep sediments when the carbonate rocks occur in a sedimented habitat (e.g., clam bed or bacterial mat) than when associated with biotic mussel beds or tubeworm bushes (Levin et al., 2015).

The community structure and ecological roles of carbonate biota within seep ecosystems and their links to AOM are just starting to be addressed. For example, a dorvilleid polychaete species dwelling within carbonates has $\delta^{13} \mathrm{C}=-92 \%$ and derives most of its 
carbon from AOM consortia (Thurber et al., 2012). Intensive trophic resource partitioning of chemoautotrophic microbes occurs among multiple species of dorvilled polychaetes in NE Pacific seep sediments (Levin et al., 2013), and among other heterotrophic meiofauna and macrofauna at hydrothermal vents (Levesque et al. 2003, Govenar et al., 2015).

Beyond stable isotope analyses, additional approaches are needed to gain insight into the functional attributes of seep biota. Biological trait analysis (BTA), a method for incorporating information about species' biological characteristics to summarize assemblage composition (Bremner et al. 2006), has been employed to inform about ecosystem function in freshwater and shallow marine benthic communities (e.g., UsseglioPolatera et al., 2000; Schratzberger et al., 2007; Marchini et al., 2008, Paganelli et al., 2012; Menezes et al., 2010, Van der Linden et al., 2012). To date there has been little application to the deep sea or to hard substrate ecosystems. Although macrofaunal communities on authigenic carbonates at methane seeps are now being described taxonomically, information about biological trait structure, with respect to lifestyle, mobility, size, feeding mode and calcification, may provide additional insight into the function of these ecosystems.

At the class and order level the carbonate fauna resembles rocky shore communities (Levin et al., 2015; Grupe et al., 2015) with dominance by grazing gastropods, although microbes rather than algae form the base of the food chain. In shallow marine settings gastropods are notorious for being keystone consumers - i.e. they control the biomass and diversity of algae and often other biota through their intense grazing activity (Lubchenco, 1978; Dayton, 1971, Branch \& Moreno, 1994). Gastropods can be extraordinarily abundant on hard substrates at both hydrothermal vents and methane seeps; with multiple genera co-occuring (Waren \& Bouchet, 1989, 2009; Waren et al., 2006, Genio et al. 2013). The high density and rapid colonization ability of some gastropod taxa at vents (Kelley \& Metaxas, 2008) and seeps (Gaudron et al. 2010; Cunha et al. 2013a; Grupe, 2014) suggest potential for gastropod grazing activities to control microbial cover and possibly composition in chemosynthetic ecosystems. Additional common consumers that appear to process significant amounts of methane-derived $\mathrm{C}$ at methane seeps include ampharetid polychaetes, which consume aerobic methane-oxidizing bacteria (Thurber et al., 2014), dorvilleid polychaetes which consume the AOM consortia (Thurber et al., 2012), and lepetopsid limpets which can graze carbonate directly (Levin et al., 2015).

Climate change is leading to a range of ocean responses that may impact environmental conditions at methane seeps on continental margins (Levin and Le Bris, 2015). These changing ocean conditions will also have consequences for the structure of communities on authigenic carbonates. Warming of bathyal waters or shifts in warm currents may dissociate gas hydrates, leading to more widespread seepage and/or higher fluxes on continental margins (Phrampus and Horbach, 2012). Warmer waters also hold less oxygen, raise metabolically driven oxygen consumption, may lead to intensified upwelling of low-oxygen waters (Bakun, 2010; Bakun et al., 2015), and exhibit increased stratification thereby reducing ventilation - all contributing to ocean deoxygenation (Keeling et al., 2010). Because of these effects and intensification of a poleward-moving undercurrent, oxygen levels on the NE Pacific margin and in the California Current system 
have been declining over the past 25-50 y (Bograd et al., 2015). Thus, understanding how methane seep communities respond to variation in methane seepage and oxygenation of overlying waters could help predict the impacts of climate-induced environmental change.

\subsection{Objectives and Questions}

The primary objective of this study was to identify the influence of methane seepage and location on the structure of macrofaunal assemblages inhabiting authigenic carbonates. We asked: (1) Do macrofaunal abundance, composition, diversity and biological traits vary as a function of (a) high and low seepage activity and (b) location, where the shallower location (HR North - 587-618 m) is associated with higher overlying [0 $\left.\mathrm{O}_{2}\right](0.34-0.52 \mathrm{ml} / \mathrm{l})$ and the deeper location (HR South $-775-800 \mathrm{~m}$ ) is associated with lower [ $\left.\mathrm{O}_{2}\right](0.24 \mathrm{ml} / \mathrm{l})$. To understand the role of methane seepage and depth location (oxygenation) we sampled carbonates from three active and three inactive seepage sites each at HR North at the boundary of the oxygen minimum zone (OMZ) and at HR South within the center of the OMZ. The functional (biological) attributes of the macrofauna were characterized with respect to feeding guild, mobility, lifestyle, body size and calcification and were analyzed as a function of seepage activity and location. The dynamic effects of seepage onset and cessation were studied by transplanting carbonates between active and inactive sites at HR North and recovering rocks after 13 months to examine community structure.

\subsection{Methods}

\subsection{Field sites and characteristics}

Investigations were carried out on the northern and southern mounds of Hydrate Ridge (HR) located on the Cascadia margin off Oregon, USA. We refer to these sites as HR-North $\left(44^{\circ} 40^{\prime} \mathrm{N}, 125^{\circ} 6^{\prime} \mathrm{W}\right)$ and HR-South $\left(44^{\circ} 34^{\prime} \mathrm{N}, 125^{\circ} 9^{\prime} \mathrm{W}\right)$ (Fig. 1). HR South sampling was done at and near the base of a carbonate edifice called the pinnacle at depths of 775-800 $\mathrm{m}$. HR North sampling was carried out on mixed substrate of carbonate slabs and shallow sediments at depths of 587-615 m (Table 1). The region has been extremely well studied with respect to geophysics, hydrology and geochemistry (Tryon et al., 1999, 2002), carbonate formation (Greiner et al., 2001; Teichert et al., 2005), seep microbiology (Boetius and Suess, 2004, Boetius et al., 2000; Marlow et al., 2014, Case et al., 2015), and the biology of seep sediments (Sahling et al., 2002, Levin et al., 2010, Guilini et al., 2012). Sampling was done from the RV Atlantis on leg AT 15-68 in Aug. 2010 using the submersible ALVIN and on leg AT 18-10 in Sept. 2011 using the ROV Jason. Sampling was conducted at 6 sites with evidence of high seepage activity, based on presence of visible, surficial microbial mats or methane bubbling, and 6 sites termed inactive - exhibiting no microbial mats, bubbles or obvious seep fauna (Fig. 2; Table 1). From 2-6 carbonate rocks were collected for macrofaunal analysis from each of the 12 sites, for a total of 45 rocks (Table 2).

Transplant experiments were conducted to examine short-term (13-mo) response of carbonate communities to seepage cessation (quiescence) or seepage activation. Fluid flux studies at HR and northern CA seeps indicate that seepage changes are frequent and can be abrupt, occurring over several weeks to months (Tryon et al., 1999, 2002; Levin et al., 2003). Four carbonate rocks were transplanted from active to inactive seep sites and vice versa at HR North using ALVIN in August 2010 (Fig. 3; Table 1). The rocks were 
carefully lifted by the manipulator arm and placed on top of the basket bioboxes, transported to a site with different activity, then placed on the sea floor, photographed, and marked with a stake nearby. Four additional rocks were lifted by the manipulator and replaced as manipulation controls at active and inactive sites. Carbonates were recovered by Jason with the assistance of a gear elevator 13 months later (Sept. 2011). Two of the inactive to active transplants were lost due to incorrect recovery (mistaken identity). Assemblage data from two non-manipulated active rocks that were mistakenly recovered (originally thought to be transplants) were treated as active controls.

Each carbonate rock was recovered in a separate biobox compartment (on ALVIN or the gear elevator) to allow whole-community analysis, as individuals often fall off the rocks during transport to the surface. Biobox inserts containing rocks were placed in a cold room $\left(5^{\circ} \mathrm{C}\right)$ immediately after recovery on board ship until samples could be processed. Rocks were photographed and macrofauna $(>0.3 \mathrm{~mm})$ were removed from the rocks, biobox and biobox water. Rocks were left in standing water in the lab at room temperature overnight to allow additional faunal to crawl out from the interior. All macrofauna were either enumerated and counted live or preserved in $8 \%$ buffered formalin for later counting and identification.

Rock surface area was determined for 38 of the carbonate rocks (Table 2) by wrapping intact carbonates in a mono-layer of tin foil and weighing the tin foil. Foil weight was divided by the weight of $1 \mathrm{~cm}^{2}$ of foil to obtain the total surface area in $\mathrm{cm}^{2}$. Faunal counts per carbonate rock were standardized to $200 \mathrm{~cm}^{2}$ surface area for analysis. For seven rocks we were unable to obtain surface area; faunal counts from these were included in diversity analyses where standardized density was not essential. Because carbonate rocks are porous, with holes and crevices, the wrapping method underestimates actual surface area. Rock volume displacement is another way to estimate rock size, however, such data were not available in this study. We note that analyses of carbonate rocks from Costa Rica seeps indicate that wrapped surface area is reasonably well correlated with volume displacement $\left(n=14, R^{2}=0.80 ; P<0.0001\right)$ (Levin and Grupe, unpublished data).

Following surface area determination, many of the same background rocks and transplant experiments were sampled on board ship for stable isotopic analyses and for microbial characterization by members of the Orphan laboratory. The influence of seepage on bacterial and archaeal composition is discussed in Marlow et al. (2014a, b). Microbial responses to the transplant treatments are described in Case et al. (2015).

\subsection{Laboratory processing.}

In the laboratory all preserved faunal samples were re-washed through a $0.3 \mathrm{~mm}$ mesh and the retained fauna were sorted under a dissecting microscope and identified to the lowest taxonomic level possible and counted. Macrofaunal taxa were characterized as belonging to one of 3 body size categories (small $(>0.3-2 \mathrm{~mm})$, medium $(2-5 \mathrm{~mm})$, large > $5 \mathrm{~mm}$ ), 7 feeding guilds (filter feeder, bacterial grazer, surface-deposit feeder, subsurfacedeposit feeder, carnivore, omnivore and chemosynthesis via symbionts), 4 lifestyles (tube builder, burrower, errant and sessile-attached), 3 mobility modes (motile, discretely 
motile, sessile), and 3 calcification categories (heavy, light or partial, none) (see Supplement 1). Relative proportions of each trait within categories were calculated as a function of location and seepage activity.

\subsection{Statistical Analyses.}

Univariate Analysis. To test for location (HR North vs HR South) and seepage activity (active vs inactive) effects on macrofaunal density, diversity metrics, and biological traits, a permutational ANOVA (PerANOVA) statistical approach was applied (Anderson et al. 2008), as a varying number of samples per treatment resulted in an unbalanced design. To test for interactions in the background rocks a univariate permutational ANOVA (perANOVA) was performed using location and activity as fixed factors. A similar univariate approach was applied to the transplant experiment data, but with a single fixed factor. A square root transformation was used to reduce the bias of abundant taxa in the transplant data and a distance-based Euclidean matrix was produced for each data set. Type III sum of squares with 9999 unrestricted permutations of the raw data was used to account for small sample sizes. Post-hoc Pairwise tests were performed when a factor with more than two levels was significant. The perANOVA analysis was performed using Primer v.6 PERMANOVA+ software.

Community composition analysis. Multidimensional scaling (MDS) was carried out on standardized taxonomic composition data for macrofauna on background rocks and on rocks in the transplant experiment using Bray-Curtis similarity matrices. Data were $4^{\text {th }}$ root transformed and 2-way ANOSIM was conducted to assess the significance of assemblage differences as a function of (a) factor (location and seepage activity) for background rocks and (b) seepage treatment (active control, inactive to active transplant, active to inactive transplant and inactive control) for the transplant experiment rocks. SIMPER was used to determine which taxa contributed to significant differences among factors or treatments.

Biological Trait analysis. MDS using Bray-Curtis similarity matrices was carried out for macrofauna on untransformed data from background rocks and transplant experiment rocks, with biological trait data tallied in two ways - (1) as presence/absence by species (counting the number of species exhibiting each trait) and (2) weighted by the number of individuals exhibiting each trait, independent of species. ANOSIM was applied to examine the influence of factor (location and seepage activity) or transplant treatment (as above); SIMPER was carried out to examine which traits contributed to differences among rock assemblages.

\subsection{Results}

\subsection{Background Rocks}

\subsubsection{Abundance and composition.}

Densities were higher at actively seeping sites at Hydrate Ridge North $(61.5 \pm 31.0$ ind $\left./ 200 \mathrm{~cm}^{2}\right)$ and South $\left(29.8 \pm 14.7 \mathrm{ind} / 200 \mathrm{~cm}^{2}\right)$ than at inactive sites $(12.7 \pm 7.0 / 200$ $\mathrm{cm}^{2}$ at HR N and $10.8 \pm 8.7 \mathrm{ind} / 200 \mathrm{~cm}^{2}$ at HR S) (Pseudo F = 5.840; $\mathrm{P}=0.020$ ) (Table 3A); 
There was no significant location effect (HR North vs South) $(\mathrm{P}=0.245)$ or interaction between location and seepage $(\mathrm{P}=0.299)$.

Despite differences in density, active and inactive sites overall had a similar representation of annelids (48-49\%). However, gastropods (provannid snails and pyropeltid limpets) comprised much of the remainder (44\%) at active sites whereas crustaceans (gammarid amphipods), echinoderms (mainly ophiuroids) and other taxa such as hydroids were common at inactive sites (Table 3B, Fig. 4). Notably, the gastropods were most abundant at HR North active sites and less well represented at HR South active sites (Fig. 4).

There was no significant difference in taxonomic composition of carbonate macrofauna between HR North vs South active sites as revealed by multidimensional scaling (Fig. 5A) (ANOSIM $\mathrm{P}=0.402$ ); the assemblages exhibited $65 \%$ dissimilarity in composition (SIMPER). There was however, a significant difference between composition at HR North vs South inactive sites (ANOSIM P=0.015), with 79\% dissimilarity (SIMPER). About half of the species were shared between HR North and South: $46 \%$ for HR North vs South active and $49 \%$ for HR North vs South inactive (Supplement 2).

There was a significant effect of seepage activity (active vs inactive) on composition within locations - at HR North (ANOSIM $R=0.416, P=0.0002)$ and HR South $(R=0.256, P=0.003$ ) (Fig. 5A). Activity-based differences in composition were driven by higher densities on active rocks of syllid (Exogoninae) ampharetid, and cirratulid polychaetes, provannid snails, pyropeltid limpets, and nemerteans and higher densities of ophiuroids, isopods, gammarid amphipods, hydroids, Typosyllis, and tanaids on inactive rocks (SIMPER). Taxa present on inactive but not active carbonates included the scallop Bathypecten, cup corals, Leptochiton, Capitella sp., hydroids, and cumaceans (Supplement 2).

\subsubsection{Diversity}

Rank abundance plots for carbonate faunas (Fig. 6A) reflect considerably greater dominance (and reduced evenness) at the active sites, but few differences between HR North and South for a given activity level. Carbonate faunas on rocks at active sites exhibited higher average species richness (PerANOVA Pseudo-F=4.274; $\mathrm{P}=0.044$ ) and reduced evenness (Pseudo-F=12.683; $\mathrm{P}=0.002)$, but similar Shannon Wiener $\left(\mathrm{H}^{\prime} \log \right.$ )$(\mathrm{P}=0.988)$ and rarefaction diversities $\left(\mathrm{ES}_{10}=5.4\right.$ vs 5.8$)(\mathrm{P}=0.299)$ (Table 3A; Fig. 6B). There were no location effects or significant interactions between location and seepage activity.

\subsubsection{Biological Traits}

Univariate analysis of feeding traits (2-way PerANOVA) revealed no effect of location (HR North vs HR South) on feeding, lifestyle, motility, size or calcification traits. Seepage activity, however, affected traits within all of these categories (Fig 7). Bacterial grazers (Pseudo-F=21.145; $\mathrm{P}=0.0002$ ) were significantly better represented on carbonates at active than inactive sites, whereas surface-deposit feeders were more common at inactive sites (Pseudo- $\mathrm{F}=11.512 ; \mathrm{P}=0.002$ ). Errant species were more common (Pseudo- $\mathrm{F}=13.34$; $\mathrm{P}=0.001$ ) and burrowers less common (Pseudo- $\mathrm{F}=6.413 ; \mathrm{P}=0.0156$ ) at active than inactive 
sites. Small species were more common at active sites (Pseudo-F =6.492; $\mathrm{P}=0.014$ ) whereas medium size species were more common at inactive sites (Pseudo- $\mathrm{F}=15.202$; $\mathrm{P}=0.0002$ ). Motile species were more common at active sites (Pseudo- $\mathrm{F}=13.098 ; \mathrm{P}=0.001$ ) and discretely motile species were more common at inactive sites (Pseudo- $\mathrm{F}=7.319$; $\mathrm{P}=0.010$ ), with no significant effect for sessile species. Heavy calcification was more common at active sites (Pseudo- $\mathrm{F}=12.062$; $\mathrm{P}=0.001$ ), whereas species without any calcification were more common at inactive sites (Pseudo-F=12.768; $\mathrm{P}=0.001$ ). None of the traits exhibited location effects or interaction between location and seepage activity.

There were no significant differences in assembled biological traits (tallied by species) between HR North and HR South (2-Way crossed ANOSIM R=0.027, P=0.246), but there was a difference between rocks at active vs inactive sites ( $R=0.112, P=0.039)$ (Fig. 5B). At active sites there were more mid-sized species with motile, errant lifestyles, bacterial grazing, and either heavy or no calcification, relative to inactive sites. Similar patterns were observed when assembled biological traits were tallied by number of individuals (using density data) (2-Way crossed ANOSIM) (Fig. 5C). There was no effect of location $(\mathrm{R}=0.044 ; \mathrm{P}=0.174)$ but seepage activity had a significant effect $(\mathrm{R}=0.234 ; \mathrm{P}=0.001)$, driven by higher densities at active sites of heavily calcified, motile, and bacterial grazing species.

\subsection{Transplant experiments.}

Carbonate rocks from Hydrate Ridge North were transplanted between active and inactive sites to better understand the influence of seepage activity on species composition, dominance patterns and the rate at which the onset or cessation of seepage acts on the different faunal assemblages. Total faunal densities were an order of magnitude (or higher) on active control rocks and on inactive rocks transplanted to active sites than for active rocks transplanted to inactive sites or inactive controls (Table 4). Significant density differences were observed on the active to inactive transplants relative to the active controls ( $\mathrm{t}=5.398 ; \mathrm{P}=0.0002)$ and between the active and inactive controls $(\mathrm{t}=3.823$; $\mathrm{P}=0.002$ ). The transplanted rocks took on the dominant species (Table 4, Fig. 8A) and rank abundance patterns (Fig. 9A) of their new sites.

The transplanted rocks exhibited reduced diversity expressed as species richness (Table 4) and rarefaction diversity (Fig. 9B), with significant differences only between active controls and active to inactive transplants $(\mathrm{t}=3.037 ; \mathrm{P}=0.012$ for $\mathrm{S}$ and $\mathrm{t}=1.399 ; \mathrm{P}=0.009$ for ES(10). Evenness was significantly lower in the active controls $\left(J^{\prime}=0.72\right)$ than in the inactive controls $\left(J^{\prime}=0.93\right)(t=3.635 ; \mathrm{P}=0.0071)$ and active to inactive transplants $\left(\mathrm{J}^{\prime}=0.94\right)$ $(\mathrm{t}=3.734 ; \mathrm{P}=0.0048)$. In terms of species presence/absence the active fauna emerged more quickly on rocks transplanted to the active sites and remained longer on rocks transplanted from active to inactive sites. These shared $60 \%$ and $45 \%$ of species with active controls, respectively (Fig. 9C). In contrast the inactive faunas were acquired by rocks transplanted to inactive sites more slowly, but were lost more quickly when transplanted to active sites. These rocks shared only $25 \%$ and $33 \%$ of the inactive control species, respectively (Fig. 9C). 
Rocks transplanted to active sites were heavily dominated by provannid snails (P. laevis and P. lomana) and pyropeltid limpets ( $P$. corymba and P. wakefieldi), as well as ampharetid and cirratulid polychaetes (Table 4). Together these comprised 95\% of the transplant fauna and $90 \%$ of the control fauna at active sites. Common active-site species $(>1 \%)$ that did not appear on the transplanted rocks included the polychaetes Exogoninae, hesionid, nereid, and lacydonid polychaetes. In contrast, Porifera and aplacophorans, characteristic of inactive carbonates, appeared to survive the 13-mo transplant. Crustaceans and echinoderms were not found on the rocks transplanted to active sites (Supplement 3).

Rocks transplanted from active to inactive sites supported low numbers of individuals, but a diverse mix of polychaetes (42\%), gastropods (23\%), crustaceans (22\%) and echinoderms (11\%) (Table 4, Supplement 3). The thirteen species present included representatives of active sites that survived reduced seepage $(P$. lomana, $P$. corymba, $P$. laevis, Nereis sp., cirratulids) and species characteristic of inactive sites that appear to have colonized including polynoids, ophiuroids, gammarid amphipods and isopods (Table 4, Supplement 3). Overall the inactive transplants and inactive controls exhibited a more even representation of species (Fig. 8B), whereas dominance was greater in the active transplants and active controls.

As with the background rocks, trait-based analysis of transplanted and control rock faunas indicate a distinction based on exposure to seepage. This was true for trait analysis based on species counts (Fig. 8B, MDS: $\mathrm{R}=0.38$; $\mathrm{P}=0.003$ ) and on numbers of individuals (Fig. 8C; MDS: $\mathrm{R}=0.635 ; \mathrm{P}=0.0004)$. On the basis of numbers of species, the traits represented on the transplanted rocks were not significantly different from the traits on the control rocks at their transplant destination; the faunal traits on the two transplant treatments also were not significantly different from each other (ANOSIM, $\mathrm{P}=0.400$ ). The active control rock traits differed from the inactive control $(\mathrm{P}=0.005)$ and the active to inactive transplant rock $(\mathrm{P}=0.010)$ traits (Table 5). The trait differences among controls primarily involved more, large, filter-feeding, sessile, lightly calcified species on the inactive controls and more tube builders and bacterial grazers on the active controls (SIMPER). The trait differences between active to inactive transplants and active controls however, were largely due to greater numbers of small, sessile or discreetly motile, surface-deposit feeding, burrowing, and bacterial grazing species (SIMPER).

When traits were analyzed for numbers of individuals, the results were similar to the species analysis (Table 5). The only trait differences were between the active control and the active to inactive transplants $(\mathrm{P}=0.005)$ or the inactive control $(\mathrm{P}=0.005)$. These differences were due to more heavily calcified, bacterial grazing, errant/motile, medium sized individuals on the active control rocks (SIMPER). Traits of fauna on rocks transplanted from active to inactive sites did not differ from those of the inactive controls after 13 mo (ANOSIM, $\mathrm{P}=0.371$ ); they also did not differ significantly from traits on the inactive to active transplants (ANOSIM, $\mathrm{P}=0.133$ ), and these did not differ from traits on the inactive controls either $(\mathrm{P}=0.067)$. Trait differences between the control treatments $(\mathrm{P}=0.005)$ were driven by much higher numbers of heavily calcified, errant, motile, 
bacterial grazing and tube building individuals on the active than inactive controls (SIMPER).

The transplanted rocks rapidly acquired individuals with the calcification traits of the new site; there were large numbers of more calcified individuals at active sites and more lightly calcified individuals at inactive sites (Fig. 10). However the active to inactive transplants did not acquire the same proportion of sessile, tube-building, filter-feeding and surfacedeposit feeding individuals as on the inactive controls (Fig. 10).

\subsection{Discussion}

\subsection{Seepage and 0xygenation Effects}

Level of methane seepage activity has long been recognized as a key agent structuring invertebrate communities at seeps both directly by fueling microbial food sources and indirectly through its influence on foundation species (reviewed in Sibuet and Olu-Le Roy, 2002; Levin, 2005; Cordes et al., 2010). At Hydrate Ridge, seepage activity has a strong influence on density, species evenness, taxonomic composition, and biological traits of macrofauna on carbonates. This was evident in both the background rocks and in the transplant experiments. The trends are similar to those observed for macrofauna on carbonates at Costa Rica seeps (Levin et al., 2015). Densities and diversity was higher on rocks exposed to active seepage, with multiple species of gastropods and polychaetes dominant, and more crustaceans, cnidarians, and ophiuroids on rocks at inactive sites. At Costa Rica seeps the tubeworm and mussels habitats supported different carbonate communities than clam bed and microbial mat habitats (Levin et al., 2015), but only these latter two habitats were present at HR (Sahling et al., 2002; Levin et al., 2010).

\subsection{Densities and Composition}

Macrofaunal densities on carbonates at active Hydrate Ridge sites (30-60 ind $/ 200 \mathrm{~cm}^{2}$ ) were lower than those at active Costa Rica margin seeps (84-212 ind. $\left./ 200 \mathrm{~cm}^{2}\right)$ but the Costa Rica sites were located in deeper, better-oxygenated waters. In contrast, the densities on carbonates at inactive HR sites $\left(11-13\right.$ ind. $\left./ 200 \mathrm{~cm}^{2}\right)$ were similar to those at inactive Costa Rica margin sites $\left(12-14 \mathrm{ind} / 200 \mathrm{~cm}^{2}\right)$ at comparable depths $(400-740 \mathrm{~m})$ within the OMZ. These densities were notably lower than those at deeper, betteroxygenated inactive Costa Rica sites (990-1402 m) (20-86 ind./200 cm²). Overall the seep densities are lower than those reported for macrofauna on shallow-water rocky shores and whale falls, but comparable to those for Mn nodules and deep-sea rocks (see summary table in Levin et al., 2015).

The HR North and HR South sites are located at $600 \mathrm{~m}$ and $800 \mathrm{~m}$, respectively. As a result HR South carbonates are bathed in overlying water that is lower in oxygen content $(0.2-$ $\left.0.3 \mathrm{ml} / \mathrm{L} \mathrm{O}_{2}\right)$ than HR North ( $\sim 0.5 \mathrm{ml} / \mathrm{l} \mathrm{O}_{2}$ (Levin et al., 2010). As observed for Costa Rica carbonates (Levin et al., 2015) hydrography of overlying waters, particularly oxygen did not appear to generate differences in HR carbonate communities at actively seeping sites (ANOSIM, $\mathrm{P}=0.492$ in a comparison of HR North and South). There was however, a significant difference in composition at inactive HR North vs HR South sites. These differences were associated with higher densities of ampharetids and terebellid polychaetes, gammarid and tanaid crustaceans, and hydroids at HR North inactive sites 
and higher densities of cirratulid and polynoid polychaetes, and ophiuroids at HR South inactive sites. The dissimilarity observed for inactive carbonate communities at HR North vs South $(79 \%)$ was greater than that reported for off-seep sediment communities at comparable depths (61\% dissimilarity at 500 vs $800 \mathrm{~m}$ ) by Levin et al. (2010). It remains to be tested whether the well-developed oxygen minimum is critical as indicated for inactive carbonate communities on the Costa Rica Margin (Levin et al. 2015), or other depth-related factors are key in structuring the inactive carbonate communities at Hydrate ridge.

Active methane seepage supports a diverse grazing fauna. Many of the gastropod genera present on carbonates at Hydrate Ridge (e.g., Provanna, Pyropelta, Hyalogyrina, Margarites) are characteristic of seeps in the W. and E. Atlantic (Waren and Bouchet, 2009; Cunha et al., 2013b) as well as in extant and fossil seeps on the US West Coast (Kiel, 2010; Levin et al., 2015). The prevalence of provannid snails, pyropeltid limpets and ampharetid and polynoid polychaetes on HR carbonates occurs in common with other hard substrate vent, seep and whale fall communities from the Pacific (e.g., Smith and Baco, 1998; Bergquist et al., 2007; Levin et al., 2015) and even soft sediments (Bernardino et al., 2012). However the dominance of syllids (Exogone and Typosyllis) and cirratulids (Cirratulus sp.) at Hydrate Ridge is distinctive. Shipboard experiments exposing carbonate macrofauna to isotopically labeled $\mathrm{H}^{13} \mathrm{CO}_{3}$ for 3-4 d reveal that the cirratulids, exogonid syllids, ampharetids, and both $P$. laevis and $P$. lomana can rapidly acquire ${ }^{13} \mathrm{C}$, presumably through consumption of sulfide oxidizing bacteria (L. Levin and V. Orphan, unpublished), as they are not known to bear symbionts.

\subsection{Hard vs soft substrate communities at seeps}

The density and diversity of macrofauna in active seep sediments (clam bed and microbial mat habitats) and near-seep sediments have been documented at Hydrate Ridge South by Levin et al. (2010) and it is possible to draw comparisons with nearby carbonate communities, although we note that sediment sampling occurred 4-5 years earlier. All carbonate macrofaunal densities, which ranged from 540 and $630 \mathrm{ind} / \mathrm{m}^{2}$ at HR South and North inactive sites, to 1490-3075 ind $/ \mathrm{m}^{2}$ at HR South and North active sites (Table 3A), were lower than those reported for macrofauna in sediments at, near and off of Hydrate Ridge (Levin et al., 2010). The active carbonate densities were 5-13 times lower than reported for HR active seep sediments $\left(16,407\right.$ ind./ $\mathrm{m}^{2}$ in microbial mat and 19,777 ind $/ \mathrm{m}^{2}$ in clam bed sediments) whereas the inactive carbonate densities were 47-55 times lower than reported for corresponding macrofauna in near-seep sediments $(29,607$ ind $/ \mathrm{m}^{2}$ ). The carbonate macrofaunal densities are also lower than background margin sediments at $500 \mathrm{~m}\left(10,054 \mathrm{ind} / \mathrm{m}^{2}\right)$ but approach those at $800 \mathrm{~m}\left(4,269 \mathrm{ind} . / \mathrm{m}^{2}\right)$. Some of the difference may be due to the greater three-dimensionality of sediments, although some of the carbonates are porous and contain an endolithofauna, including some larger taxa. However, even in sediments, most seep infauna live fairly near the surface where sulfide concentrations are lower (Levin et al., 2003). We suspect that greater food availability in sediments contributes to the density differences observed between hard and soft substrates at Hydrate Ridge.

The carbonate communities of both active and inactive sites at HR North and South had 
lower diversity $\left(\mathrm{H}^{\prime} \log\right.$ e $=1.76-2.05$; Table $\left.3 \mathrm{~A}\right)$ than observed in seep and near-seep sediments at Hydrate Ridge $\left(\mathrm{H}^{\prime} \log\right.$ e $=2.32-2.65$ by Levin et al. (2010). A similar trend was observed in comparison of carbonate and sediment diversity at Costa Rica seeps (Levin et al., 2015). At HR North and South, active sites yielded notably greater macrofaunal species evenness on carbonates $\left(J^{\prime}=0.76-0.77\right.$; Table $\left.3 \mathrm{~A}\right)$ than reported for active microbial mat sediments $\left(J^{\prime}=0.64\right)$ at Hydrate Ridge; carbonate values were more similar to those of macrofauna in clambed sediments $\left(J^{\prime}=0.73\right)$ (Levin et al., 2010). J' of carbonate macrofauna at inactive sites (0.85-0.92) reflected higher evenness comparable to that in near-seep sediments at Hydrate Ridge (0.85). Surprisingly, the Rank 1 dominance (R1D) patterns were similar between sediments and carbonates (Table $3 \mathrm{~A}$ and Levin et al., 2010). Active carbonates at HR North and South had values of 0.24 and 0.41 , respectively, compared to 0.24 and 0.33 for HR clambed and mat habitats at HR South. Inactive carbonate R1D at HR North and South (R1D $=0.15$ and 0.17 ) were comparable to those in near-seep sediments (R1D=0.19) (Levin et al., 2010).

The predominance of annelids ( $\sim 75 \%$ ) on HR South active carbonates (Fig. 4) was similar to that in HR South sediments from clambed, near seep, and background sites $(72-76 \%$ annelids) (Levin et al, 2010). A high proportion of Gastropoda, observed on HR North active carbonates (55\%) (Fig. 4) was also observed on Costa Rica carbonates in mussel beds and tubeworm bushes- among the most actively seeping sites (Levin et al., 2010, 2015). Gastropods are also abundant on carbonates at seeps in the Gulf of Cadiz (Genio et al., 2013; Cunha et al., 2013b) and the Marmara Sea (Ritt et al., 2010), but the dominant taxa at Hydrate Ridge (provannids and pyropeltids) were rare or absent at these locations.

\subsection{Insights from Transplant Experiments}

The transplant experiments revealed the potential for rapid $(<13-\mathrm{mo})$ response of assemblages to increase or cessation of seepage, but also revealed abilities for some taxa characteristic of one seepage scenario to persist in the face of change. Provannid and pyropeltid gastropods rapidly increased representation on inactive rocks transplanted to active sites; notably, only a very few individual $P$. lomana and $P$. corymba were able to survive when moved from active to inactive sites. Most species common under inactive conditions disappeared from rocks when transplanted to active sites, but Porifera and aplacophorans survived the 13 -mo shift from inactive to active seepage conditions.

Many of the species common on carbonates at active sites are microbial grazers (Fig. 7), so their fates in transplant experiments may track those of the microbes. Rocks transplanted from active to inactive sites had 30\% lower microbial operational taxonomic unit (OUT) richness than active control rocks, and $52-58 \%$ of active site OTUs were lost, although some new ones (characteristic of inactive conditions) were acquired (Case et al. 2015). Notably, among sulfide oxidizers, epsilonproteobacterial Helicobacteriaceae OTUs characteristic of active carbonates had mostly disappeared after 13 months of simulated seep quiescence, whereas the gammaproteobacterial Thiotrichaceae OTUs persisted, exhibiting resilience to seep quiescence. Some archaea (ANME-1) increased in relative abundance over 13 mo on rocks transplanted from active to inactive sites. For carbonates transplanted from inactive to active sites, epsilonproteobacterial Helicobacteraceae OTUs recovered to high relative abundance, while gammaproteobacterial Thiotrichaceae, and 
heterotrophs (Chloroflexi, the Anaerolineaceae and Caldilineaceae) exhibit little/slow recovery (Case et al., 2015).

The majority of heterotrophs at vents and seeps rely on microbial food sources. Recent studies have shown the potential for diet specialization among some microbial grazers notably dorvilleid polychaetes (Levin et al., 2013) and gastropods (Govenar et al, 2015; Levin et al., 2015) at vents and seeps. Sequenced gut contents of hydrothermal vent limpets reveal several species that specialize on epsilonproteobacteria while others have a more diversified diet; researchers suggest these diet differences are linked to different fluid flux environments (Govenar et al., 2015). The HR transplant results suggest that the provannid and pyropeltid gastropods abundant on carbonates at HR active sites might specialize on epsilonproteobacteria, and do not survive in their absence. This may be especially true for P. laevis and P. wakefieldi, which were not present on the transplanted or control rocks at the inactive sites. Stable isotope analyses of the individuals on transplanted rocks reveal diet shifts during the 13-mo experimental period (Grupe, 2014). Macrofaunal assemblages on both groups of transplanted carbonates had mean $\delta^{13} \mathrm{C}$ and $\delta^{15} \mathrm{~N}$ that fell in between those of control active and inactive carbonates (Grupe, 2014).

The effect of higher fluid flow rates on organismal performance has been demonstrated for bathymodiolin mussels subjected to similar experimental transplants between microhabitats at hydrothermal vents (Smith 1985) and hydrocarbon seeps (Dattagupta et al., 2004). Manipulation of sediments in colonization trays at northern California seeps also revealed a major influence of proximity to seepage on colonizer density and composition, but it was unclear whether this was a result of geochemical cues or proximity to larval sources (Levin et al., 2006).

Recent work by Marlow et al. (2014a) on carbonates from the Hydrate Ridge sites indicates that seepage level has less effect on bacterial diversity than on the distribution of anaerobic archaeal methanotrophs, and that while seepage may serve as an overlaid imprint on bacterial community structure, carbonate permeability, mineralogy, and local hydrology have a more significant role in determining bacterial assemblages. This information, combined with the finding that apparently inactive carbonates support significant internal microbial activity (Marlow et al., 2014b) and with transplant results showing different microbial sensitivities to changes in seepage (Case et al., 2015), raise many questions about the extent to which the presence and abundance of specific microbial taxa may structure macrofaunal assemblages through trophic processes. An understanding that many of the carbonate taxa consume bacteria, are relatively motile, may select for or assimilate specific microbial food sources (Levin et al., 2015), and can respond to environmental changes rapidly (this study), introduces potential for extensive (and subtle) spatial and temporal dynamics on seep carbonates. The relative importance of bottom-up (microbial) interactions, competitive interactions, and top-down (predator) influences, the time scales over which they act, and the resulting stages of transition from active seeps to inactive to background communities remain to be investigated.

\subsection{Trait -based patterns}


In the literature, biological trait analysis of macrofaunal invertebrates has been employed in a comparative manner to examine community functional response to environmental conditions, disturbance or status. Bonada et al. (2007) for example, compared stream macroinvertebrates in Mediterranean systems having high flood and drought variability with more stable temperate systems, and found trait composition less sensitive to climateinduced variability than taxonomic composition. In contrast, Usseglio-Polatera et al. (2000) and Van der Lindena et al. (2012) found that biological trait analysis could detect ecosystem transitions in rivers and estuaries where taxonomic analysis alone could not. Biological trait analysis has been proposed as a tool for understanding faunal associations with seafloor properties (e.g., Schratzberger et al., 2007), monitoring change in benthic ecosystems as a result of dredging (Cooper et al., 2008), assessing ability to provide ecosystem services such as waste processing (Bremner et al., 2003), biodiversity conservation (Statzner et al., 2007), and designation and management of marine protected areas (Frid et al., 2008).

On Hydrate Ridge carbonates, biological trait patterns aligned largely with seepage and were fairly consistent between HR North and South (Fig. 7). Actively seeping sites were characterized by motile, bacterial grazing, small- and medium-sized species, whereas inactive sites exhibited a greater diversity of feeding modes including more omnivores and filter feeders, more sessile and burrowing species, more large and lightly calcified species (mainly crustaceans). Heavy calcification was a distinctive feature of active sites at HR North; this was less evident at HR South.. The transplant studies demonstrated that feeding mode, size structure and calcification patterns can shift rapidly (within $13 \mathrm{mo}$ ) when seepage changes (Fig. 10). This was less true of lifestyles and motility patterns, as the sessile, attached species did not track seepage as quickly (Fig. 10); they survived on rocks when transplanted from inactive to active seepage sites. The high abundance of predators (e.g., polynoid and nereid polychaetes, and phoxocephallid amphipods) on the inactive transplants may reflect scavenging on animals that died following transplantation. Relatively high motility may be beneficial for species reliant on chemosynthetic food sources, allowing them to respond to changes in microbial productivity induced by seepage variations. From these studies we can infer that variation in seepage activity generates heterogeneity in macrofaunal feeding, lifestyles, body size, motility and calcification in ways that may enhance functional diversity and trophic complexity.

The high incidence of heavily calcified gastropods at actively seeping HR North sites might be somewhat paradoxical, given the low $\mathrm{pH}$ of seep fluids and the elevated $\mathrm{CO}_{2}$ content of oxygen minimum zone waters that overlay the sites. However, anaerobic methane oxidation metabolism produces DIC ( $\mathrm{HCO}_{3}$ ) and alkalinity in a $1: 2$ ratio, making active seeps favorable for both authigenic and biological carbonate precipitation. Also, given that calcification under low-pH conditions is often energy-constrained, it may be that seepage yields sufficient food for gastropods in the form of microbial production, such that the energetic requirements for calcification are met. It is notable that calcified gastropods are not as abundant at HR South, where overlying oxygen content is lower.

\subsection{Conclusions}


Fluid seepage exerts strong control on the density, taxonomic composition, diversity, and biological traits of macrofaunal assemblages inhabiting authigenic carbonates. Assemblage feeding mode, size structure and calcification patterns are altered rapidly (within 13 mo) when seepage is initiated or ceases. Macrofauna characteristic of carbonates under active seepage are more opportunistic; they colonize quickly at onset of seepage, but also can persist longer under unfavorable conditions. Macrofaunal assemblages on inactive carbonates do not respond/recover as quickly but can disappear rapidly under adverse conditions or competition associated with seepage. In contrast, overlying hydrography, particularly oxygenation or other depth-related variables, appears to be influential primarily under low-flux, or inactive conditions.

Given strong temporal variability in fluid seepage on week to month time scales (Tryon, 1999; Levin et al., 2003), seep carbonate macrofaunal communities are likely to be highly dynamic. A mosaic of communities changing in space and time can help explain the relatively high species diversity at methane seeps. This invokes the contemporaneous disequilibrium hypotheses originally proposed by Huston (1979) for deep-sea diversity maintenance. Biological trait analysis of the type conducted here may facilitate comparisons of dynamics across ecosystems where species composition differs, for example among methane seeps in different biogeographic regions. Biological trait patterns that can be linked to succession, disturbance or stability could be particularly useful for environmental monitoring.

We now suspect there are tens of thousands of seeps on margins around the world (Boetius and Wenzhofer, 2013). Warming waters and shifting currents are likely to increase the numbers of new seeps and expand the size of existing seeps. Both the microbes that precipitate authigenic carbonate and the associated fauna provide a biological sink, removing released methane. A more complete understanding of the bottom-up influence of seepage on the structure and function of deep-sea communities will be necessary for predicting effects of methane release on the carbon cycle, biodiversity maintenance, and other deep-sea processes.

7. Acknowledgements We thank the captain, crew, ALVIN and Jason pilots, and science participants of $R V$ Atlantis legs 15-68 and AT 18-10. We acknowledge the significant contributions of G. Rouse, V. Orphan, A. Rathburn and their lab members with assistance at sea. We express great appreciation to M. Navarro, B. Jellison, A. McGreggor, and M. Gambi for assistance during AT 15-68, and M. Nordstroem, A. Thurber, K. Sato and A. Pasulka for assistance during AT 18-10. Anders Waren also helped at sea and with mollusk identification. J. Marlow and D. Case kindly shared microbial information for carbonates. Comments by two anonymous reviewers improved the manuscript. The research was

supported by the National Science Foundation (NSF grants OCE 0826254 and OCE 0939557).

\section{Author Contributions.}

Conceived and designed the study: LAL; Carried out the field work: LAL, GFM, BMG, Performed the laboratory processing and analysis: GFM, BMG; Performed statistical analysis: GFM; Wrote the manuscript: LAL. 


\section{References}

Aloisi, G., Bouloubassi, I., Heijs, S.K., Pancost, R.D., Pierre, C., Damsté, J.S.S., Gottschal, J.C., Forney, L.J., Rouchy, J.-M., 2002. CH 4-consuming microorganisms and the formation of carbonate crusts at cold seeps. Earth and Planetary Science Letters 203 (1), 195203.

Bahr, A., Pape, T., Bohrmann, G., Mazzini, A., Haeckel, M., Reitz, A., Ivanov, M., 2009. Authigenic carbonate precipitates from the NE Black Sea: a mineralogical, geochemical, and lipid biomarker study. International Journal of Earth Sciences 98 (3), 677-695.

Bakun, A., Black, B., Bograd, S.J., Garcia-Reyes, M., Miller, A., Rykaczewski, R., Sydeman, W., 2015. Anticipated effects of climate change on coastal upwelling ecosystems. Current Climate Change Reports 1 (2), 85-93.

Bergquist, D.C., Eckner, J.T., Urcuyo, I.A., Cordes, E.E., Hourdez, S., Macko, S.A., Fisher, C.R., 2007. Using stable isotopes and quantitative community characteristics to determine a local hydrothermal vent food web. Marine Ecology Progress Series 330, 49-65.

Bernardino, A.F., Levin, L.A., Thurber, A.R., Smith, C.R., 2012. Comparative composition, diversity and trophic ecology of sediment macrofauna at vents, seeps and organic falls. PloS one 7 (4), e33515.

Birgel, D., Himmler, T., Freiwald, A., Peckmann, J., 2008. A new constraint on the antiquity of anaerobic oxidation of methane: Late Pennsylvanian seep limestones from southern Namibia. Geology 36 (7), 543-546.

Birgel, D., Peckmann, J., 2008. Aerobic methanotrophy at ancient marine methane seeps: a synthesis. Organic Geochemistry 39 (12), 1659-1667.

Boetius, A., Ravenschlag, K., Schubert, C.J., Rickert, D., Widdel, F., Gieseke, A., Amann, R., Jørgensen, B.B., Witte, U., Pfannkuche, O., 2000. A marine microbial consortium apparently mediating anaerobic oxidation of methane. Nature 407 (6804), 623-626.

Boetius, A., Suess, E., 2004. Hydrate Ridge: a natural laboratory for the study of microbial life fueled by methane from near-surface gas hydrates. Chemical Geology 205 (3), 291-310.

Boetius, A. , Wenzhofer, F. 2013. Seafloor oxygen consumption fueled by methane from cold seeps. Nature Geoscience 6, 725-734.

Bograd, S.J., Buil, M.P., Di Lorenzo, E., Castro, C.G., Schroeder, I.D., Goericke, R., Anderson, C.R., Benitez-Nelson, C., Whitney, F.A., 2015. Changes in source waters to the Southern California Bight. Deep Sea Research Part II: Topical Studies in Oceanography 112, 42-52.

Bohrmann, G., Greinert, J., Suess, E., Torres, M., 1998. Authigenic carbonates from the Cascadia subduction zone and their relation to gas hydrate stability. Geology 26 (7), 647-650.

Bonada, N., Doledec, S., Statzner, B., 2007. Taxonomic and biological trait differences of stream macroinvertebrate communities between mediterranean and temperate regions: implications for future climatic scenarios. Global Change Biology 13 (8), 1658-1671. 
Branch, G. Moreno, C.A., 1994. Moreno Intertidal and subtidal grazers, p. Chap. 5. In Siegfried WR (ed.), Rocky shores: Exploitation in Chile and South Africa. Springer Verlag, Heidelberg, Germany.

Bremner, J., Rogers, S., Frid, C., 2003. Assessing functional diversity in marine benthic ecosystems: a comparison of approaches. Marine Ecology Progress Series 254, 1125.

Bremner, J., Rogers, S., Frid, C., 2006. Methods for describing ecological functioning of marine benthic assemblages using biological traits analysis (BTA). Ecological Indicators 6 (3), 609-622.

Case, D.H., Pasulka, A.L., Marlow, J.J., Grupe, B.M., Levin, L.A., Orphan, V.J., 2015. Methane Seep Carbonates Host Distinct, Diverse, and Dynamic Microbial Assemblages. mBio 6 (6), e01348-01315.

Castilla, J.C., Manríquez, P.H., Delgado, A., Ortiz, V., Jara, M.E., Varas, M., 2014. Rocky intertidal zonation pattern in Antofagasta, Chile: Invasive species and shellfish gathering. PloS one 9 (10), e110301.

Cooper, K.M., Froján, C.R.B., Defew, E., Curtis, M., Fleddum, A., Brooks, L., Paterson, D.M., 2008. Assessment of ecosystem function following marine aggregate dredging. Journal of Experimental Marine Biology and Ecology 366 (1), 82-91.

Cordes, E.E., Cunha, M.R., Galeron, J., Mora, C., Roy, O.L., Sibuet, M., Van Gaever, S., Vanreusel, A., Levin, L.A., 2010. The influence of geological, geochemical, and biogenic habitat heterogeneity on seep biodiversity. Marine Ecology 31 (1), 51-65.

Cunha MR, Matos FL, Génio L, Hilário A, Moura CJ, et al. 2013a. Are organic falls bridging reduced environments in the deep sea? - Results from colonization experiments in the Gulf of Cádiz. PLoS ONE 8(10): e76688. doi:10.1371/journal.pone.0076688.

Cunha, M., Rodrigues, C., Génio, L., Hilário, A., Ravara, A., Pfannkuche, O., 2013b. Macrofaunal assemblages from mud volcanoes in the Gulf of Cadiz: abundance, biodiversity and diversity partitioning across spatial scales. Biogeosciences (BG) 10 (4), 2553-2568.

Dattagupta, S., Bergquist, D., Szalai, E., Macko, S., Fisher, C., 2004. Tissue carbon, nitrogen, and sulfur stable isotope turnover in transplanted Bathymodiolus childressi mussels: Relation to growth and physiological condition. Limnology and Oceanography 49, 1144-1151.

Dayton, P.K., 1971. Competition, disturbance, and community organization: the provision and subsequent utilization of space in a rocky intertidal community. Ecological Monographs 41 (4), 351-389.

Desbruyeres, D., Segonzac, M., Bright, M., 2006. Handbook of Deep-Sea Hydrothermal Vent Fauna, 544 pp. Biologiezentrum der Oberösterreichische Landesmuseen, Linz, Austria.

Frid, C., Paramor, O., Brockington, S., Bremner, J., 2008. Incorporating ecological functioning into the designation and management of marine protected areas. Hydrobiologia 606 (1), 69-79.

Gaudron, S., Pradillon, F., Pailleret, M., Duperron, S., Le Bris, N., Gaill, F., 2010. Colonization of organic substrates deployed in deep-sea reducing habitats by symbiotic species and associated fauna. Marine Environmental Research 70 (1), 1-12.

Génio, L., Warén, A., Matos, F., Cunha, M., 2013. The snails' tale in deep-sea habitats in the Gulf of Cadiz (NE Atlantic). Biogeosciences 10 (7), 5159-5170. 
Gibson, R., Atkinson, R., Gordon, J., 2005. Ecology of cold seep sediments: interactions of fauna with flow, chemistry and microbes. Oceanography and Marine Biology: an annual review 43, 1-46.

Gieskes, J., Mahn, C., Day, S., Martin, J.B., Greinert, J., Rathburn, T., McAdoo, B., 2005. A study of the chemistry of pore fluids and authigenic carbonates in methane seep environments: Kodiak Trench, Hydrate Ridge, Monterey Bay, and Eel River Basin. Chemical Geology 220 (3), 329-345.

Govenar, B., Fisher, C.R., Shank, T.M., 2015. Variation in the diets of hydrothermal vent gastropods. Deep Sea Research Part II: Topical Studies in Oceanography 121, 193201.

Greinert, J., Bohrmann, G., Suess, E., 2001. Gas hydrate-associated carbonates and methane-venting at Hydrate Ridge: classification, distribution, and origin of authigenic lithologies. Natural gas hydrates: Occurrence, distribution, and detection, 99-113.

Grupe, B.M., 2014. Implications of Environmental Heterogeneity for Community Structure, Colonization, and Trophic Dynamics at Eastern Pacific Methane Seeps. University of California, San Diego.

Grupe, B.M., Krach, M.L., Pasulka, A.L., Maloney, J.M., Levin, L.A., Frieder, C.A., 2015. Methane seep ecosystem functions and services from a recently discovered southern California seep. Marine Ecology 36 (S1), 91-108.

Guilini, K., Levin, L.A., Vanreusel, A., 2012. Cold seep and oxygen minimum zone associated sources of margin heterogeneity affect benthic assemblages, diversity and nutrition at the Cascadian margin (NE Pacific Ocean). Progress in Oceanography 96 (1), 7792.

Han, X., Suess, E., Sahling, H., Wallmann, K., 2004. Fluid venting activity on the Costa Rica margin: new results from authigenic carbonates. International Journal of Earth Sciences 93 (4), 596-611.

Heijs, S., Aloisi, G., Bouloubassi, I., Pancost, R., Pierre, C., Damsté, J.S., Gottschal, J., Van Elsas, J., Forney, L., 2006. Microbial community structure in three deep-sea carbonate crusts. Microbial ecology 52 (3), 451-462.

Huston, M., 1979. A general hypothesis of species diversity. American naturalist, 113, 81101.

Keeling, R.F., Körtzinger, A., Gruber, N., 2010. Ocean deoxygenation in a warming world. Marine Science 2.

Kelly, N., Metaxas, A., 2008. Diversity of invertebrate colonists on simple and complex substrates at hydrothermal vents on the Juan de Fuca Ridge. Aquat Biol 3, 271-281.

Kiel, S., 2010. On the potential generality of depth-related ecologic structure in cold-seep communities: Evidence from Cenozoic and Mesozoic examples. Palaeogeography, Palaeoclimatology, Palaeoecology 295 (1), 245-257.

Levesque, C., Juniper, S.K., Marcus, J., 2003. Food resource partitioning and competition among alvinellid polychaetes of Juan de Fuca Ridge hydrothermal vents. Marine Ecology Progress Series 246, 173-182.

Levin, L.A., Le Bris, N., 2015. The deep ocean under climate change. Science 350 (6262), 766-768. 
Levin, L.A., Mendoza, G.F., Gonzalez, J.P., Thurber, A.R., Cordes, E.E., 2010. Diversity of bathyal macrofauna on the northeastern Pacific margin: the influence of methane seeps and oxygen minimum zones. Marine Ecology 31 (1), 94-110.

Levin, L.A., Mendoza, G.F., Grupe, B.M., Gonzalez, J.P., Jellison, B., Rouse, G., Thurber, A.R., Waren, A., 2015. Biodiversity on the rocks: macrofauna inhabiting authigenic carbonate at Costa Rica methane seeps. PloS one 10 (7), e0131080.

Levin, L.A., Ziebis, W., Mendoza, G.F., Bertics, V.J., Washington, T., Gonzalez, J., Thurber, A.R., Ebbe, B., Lee, R.W., 2013. Ecological release and niche partitioning under stress: Lessons from dorvilleid polychaetes in sulfidic sediments at methane seeps. Deep Sea Research Part II: Topical Studies in Oceanography 92, 214-233.

Levin, L.A., Ziebis, W., Mendoza, G.F., Growney-Cannon, V., Walther, S., 2006. Recruitment response of methane-seep macrofauna to sulfide-rich sediments: An in situ experiment. Journal of Experimental Marine Biology and Ecology 330 (1), 132-150.

Levin, L.A., Ziebis, W., Mendoza, G.F., Growney, V.A., Tryon, M.D., Brown, K.M., Mahn, C., Gieskes, J.M., Rathburn, A.E., 2003. Spatial heterogeneity of macrofauna at northern California methane seeps: influence of sulfide concentration and fluid flow. Marine Ecology Progress Series 265, 123-139.

Lubchenco, J., 1978. Plant species diversity in a marine intertidal community: importance of herbivore food preference and algal competitive abilities. American naturalist, 112, 23-39.

Marchini, A., Munari, C., Mistri, M., 2008. Functions and ecological status of eight Italian lagoons examined using biological traits analysis (BTA). Marine Pollution Bulletin 56 (6), 1076-1085.

Marlow, J.J., Steele, J.A., Case, D.H., Connon, S.A., Levin, L.A., Orphan, V.J., 2014a. Microbial abundance and diversity patterns associated with sediments and carbonates from the methane seep environments of Hydrate Ridge, OR. Front Microbio 1, 44.

Marlow, J.J., Steele, J.A., Ziebis, W., Thurber, A.R., Levin, L.A., Orphan, V.J., 2014b. Carbonate-hosted methanotrophy represents an unrecognized methane sink in the deep sea. Nature communications 5.

Menezes, S., Baird, D.J., Soares, M.V.M., 2010. Beyond taxonomy: a review of macroinvertebrate trait-based community descriptors as tools for freshwater biomonitoring. Journal of Applied Ecology 2010, 47, 711-719

Menot, L., Sibuet, M., Carney, R.S., Levin, L.A., Rowe, G.T., Billett, D.S., Poore, G., Kitazato, H., Vanreusel, A., Galéron, J., 2010. New perceptions of continental margin biodiversity. Life in the World's Oceans: Diversity, Distribution, and Abundance, edited by: McIntyre, AD, 79-103.

Paganelli, D., Marchini, A., Occhipinti-Ambrogi, A., 2012. Functional structure of marine benthic assemblages using Biological Traits Analysis (BTA): a study along the Emilia-Romagna coastline (Italy, North-West Adriatic Sea). Estuarine, Coastal and Shelf Science 96, 245-256.

Peckmann, J., Thiel, V., 2004. Carbon cycling at ancient methane-seeps. Chemical Geology 205 (3), 443-467.

Phrampus, B.J., Hornbach, M.J., 2012. Recent changes to the Gulf Stream causing widespread gas hydrate destabilization. Nature 490 (7421), 527-530. 
Reitner, J., Peckmann, J., Reimer, A., Schumann, G., Thiel, V., 2005. Methane-derived carbonate build-ups and associated microbial communities at cold seeps on the lower Crimean shelf (Black Sea). Facies 51 (1-4), 66-79.

Ritt, B., Pierre, C., Gauthier, O., Wenzhöfer, F., Boetius, A., Sarrazin, J., 2011. Diversity and distribution of cold-seep fauna associated with different geological and environmental settings at mud volcanoes and pockmarks of the Nile Deep-Sea Fan. Marine Biology 158 (6), 1187-1210.

Ritt, B., Sarrazin, J., Caprais, J.-C., Noël, P., Gauthier, O., Pierre, C., Henry, P., Desbruyères, D., 2010. First insights into the structure and environmental setting of cold-seep communities in the Marmara Sea. Deep Sea Research Part I: Oceanographic Research Papers 57 (9), 1120-1136.

Sahling, H., Rickert, D., Lee, R.W., Linke, P., Suess, E., 2002. Macrofaunal community structure and sulfide flux at gas hydrate deposits from the Cascadia convergent margin, NE Pacific. Marine Ecology Progress Series 231, 121-138.

Schratzberger, M., Warr, K., Rogers, S., 2007. Functional diversity of nematode communities in the southwestern North Sea. Marine Environmental Research 63 (4), 368-389.

Scott Shapiro, R., 2004. Recognition of fossil prokaryotes in Cretaceous methane seep carbonates: relevance to astrobiology. Astrobiology 4 (4), 438-449.

Sellanes, J., Quiroga, E., Gallardo, V.A., 2004. First direct evidence of methane seepage and associated chemosynthetic communities in the bathyal zone off Chile. Journal of the Marine Biological Association of the UK 84 (05), 1065-1066.

Sibuet, M., Olu-Le Roy, K., 2002. Cold seep communities on continental margins: structure and quantitative distribution relative to geological and fluid venting patterns. Ocean margin systems. Springer, pp. 235-251.

Smith, C.R., Baco, A., 1998. Phylogenetic and functional affinities between whale-fall, seep and vent chemoautotrophic communities. Cahiers de biologie marine (3-4).

Smith, K., 1985. Deep-sea hydrothermal vent mussels: nutritional state and distribution at the Galapagos Rift. Ecology, 1067-1080.

Stakes, D.S., Orange, D., Paduan, J.B., Salamy, K.A., Maher, N., 1999. Cold-seeps and authigenic carbonate formation in Monterey Bay, California. Marine Geology 159 (1), 93-109.

Statzner, B., Bonada, N., Dolédec, S., 2007. Conservation of taxonomic and biological trait diversity of European stream macroinvertebrate communities: a case for a collective public database. Biodiversity and Conservation 16 (12), 3609-3632.

Teichert, B.M., Bohrmann, G., Suess, E., 2005. Chemoherms on Hydrate Ridge-unique microbially-mediated carbonate build-ups growing into the water column. Palaeogeography, Palaeoclimatology, Palaeoecology 227 (1), 67-85.

Thurber, A.R., Levin, L.A., Orphan, V.J., Marlow, J.J., 2012. Archaea in metazoan diets: implications for food webs and biogeochemical cycling. The ISME journal 6 (8), $1602-1612$.

Thurber, A., Sweetman, A., Narayanaswamy, B., Jones, D., Ingels, J., Hansman, R., 2014. Ecosystem function and services provided by the deep sea. Biogeosciences 11 (14), 3941-3963. 
Tryon, M.D., Brown, K.M., Torres, M.E., Tréhu, A.M., McManus, J., Collier, R.W., 1999. Measurements of transience and downward fluid flow near episodic methane gas vents, Hydrate Ridge, Cascadia. Geology 27 (12), 1075-1078.

Usseglio-Polatera, P., Bournaud, M., Richoux, P. Tachet, H. 2000. Biological and ecological traits of benthic freshwater macroinvertebrates: relationships and definition of groups with similar traits. Freshwater Biology 43, 175-205

Van der Linden, P., Patrício, J., Marchini, A., Cid, N., Neto, J.M., Marques, J.C., 2012. A biological trait approach to assess the functional composition of subtidal benthic communities in an estuarine ecosystem. Ecological Indicators 20, 121-133.

Van Dover, C.L., 2003. Variation in community structure within hydrothermal vent mussel beds of the East Pacific Rise. Marine ecology. Progress series 253, 55-66.

Warén, A., Bouchet, P., 1989. New gastropods from East Pacific hydrothermal vents. Zoologica Scripta 18 (1), 67-102.

Warén, A., Bouchet, P., 2009. New gastropods from deep-sea hydrocarbon seeps off West Africa. Deep Sea Research Part II: Topical Studies in Oceanography 56 (23), 23262349. 
Table Captions.

Table 1. Location, depth, sampling dates and dive numbers for Hydrate Ridge (HR) study sites. Transplant experiments were recovered Sept. 1-3, 2011.

Table 2. Numbers and types of carbonate rocks collected for macrofaunal analysis.

Table 3. Summary of macrofaunal (A) density and diversity and (B) Top ten taxa on carbonates at Hydrate Ridge North (HR-N) and Hydrate Ridge South (HR-S) as a function of seepage activity.

Table 4. Summary of macrofaunal density, diversity and top ten taxa for carbonates in transplant experiments at Hydrate Ridge North.

Table 5. Summary of multivariate analyses of (A) macrofaunal composition (B) biological traits tallied by species counts and (C) biological traits weighted by number of individuals on carbonates in transplant experiments at Hydrate Ridge North. Within treatment similarity is given on the diagonal, between treatment dissimilarity is given above the diagonal and $\mathrm{P}$ value for between-treatment contrasts is given below the diagonal.

\section{Figure Captions}

Fig. 1. Map of sampling sites at North and South Hydrate Ridge (HR) methane seeps. Active sampling sites are shown in red, inactive sites in blue.

Fig. 2 Representative images of (A) actively seeping and (B) inactive sites at Hydrate Ridge. Representative carbonates are shown from rocks from (C) active and (D) inactive sites.

Fig. 3 Schematic illustrating the 13-month transplant experiments conducted at Hydrate Ridge (HR) North. Carbonate rocks were moved by the ROV Jason from active to inactive sites or inactive to active sites. Controls were rocks at active or inactive sites that were picked up by the manipulator and replaced in the same area.

Fig. 4 Taxonomic composition of macrofauna on authigenic carbonates at Hydrate Ridge North (HRN) and Hydrate RidgeSouth (HRS) from actively seeping and inactive sites.

Fig. 5 Multidimensional scaling plots illustrating macrofauna on background authigenic carbonates for Hydrate Ridge North Active (HR-N_A) and Inactive (HR-N_I) sites and Hydrate Ridge South Active (HR-S_A) and Inactive (HR-S_I) sites. A. Taxonomic composition B. Biological traits tallied by number of species C. Biological traits weighted by number of individuals.

Fig. 6 Macrofaunal assemblages on background authigenic carbonates at Hydrate Ridge North (HRN) and Hydrate Ridge South (HRS) from actively seeping and inactive sites. 


\section{A. Rank abundance plot and B. Rarefaction curves}

Fig. 7. Proportional representation of biological traits for macrofauna on background authigenic carbonates at Hydrate Ridge North and South from actively seeping and inactive sites. (A) Feeding mode: SSDF= Subsurface-deposit feeder, GB=bacterial grazer, $\mathrm{SDF}=$ Surface-deposit feeder, $\mathrm{OMN}=0$ mnivore, $\mathrm{FF}=$ Filter feeder, $\mathrm{CARN}=$ Carnivore, Wood - Wood consumer, CHEM = reliant on chemosymbiotic microbes. (B) Lifestyle: BURR $=$ Burrower, ERR $=$ Errant, TUBE $=$ Tube builder, SESS $=$ Attached (C) Size: $\mathrm{sm}=$ small, $\mathrm{md}=$ medium, $\operatorname{lrg}=$ large (see text for sizes) (D) Motility: $\mathrm{M}=$ Motile, $\mathrm{DM}=$ discretely motile, SESS $=$ sessile and (E) Calcification: None $=$ non calicified, Light $=$ lightly calcified, Heavy $=$ heavily calcified.

Fig. 8. Multidimensional scaling plots for transplant experiments illustrating (A) taxonomic composition and biological traits of macrofauna on authigenic carbonates in transplant experiments (B) tallied by species and (C) weighted by number of individuals. Treatments abbreviations are: Act Trans Control = Active Controls, Inact to Act Transplant $=$ Inactive to Active Transplants, Act to Inact Transplant $=$ Active to Inactive Transplants, Inact Trans Control $=$ Inactive Controls.

Fig. 9.

Macrofaunal community attributes on carbonates in transplant experiments at Hydrate Ridge North. (A) Rank Abundance plot (B) Rarefaction curves (abbreviations as in Fig. 8) (C) Transplant Venn diagram showing number of species overlapping among treatments. (Tra=Transplant, Act = Active, Inact=Inactive)

Fig. 10. Proportional representation of biological traits for macrofauna in each of four transplant experiment treatments at Hydrate Ridge North: Active Control, Inactive to Active, Active to Inactive and Inactive Control. Traits are shown for (A) Feeding mode (B) Lifestyle (C) Size (D) Motility and (E) Calcification. Legend abbreviations as in Fig. 7. 

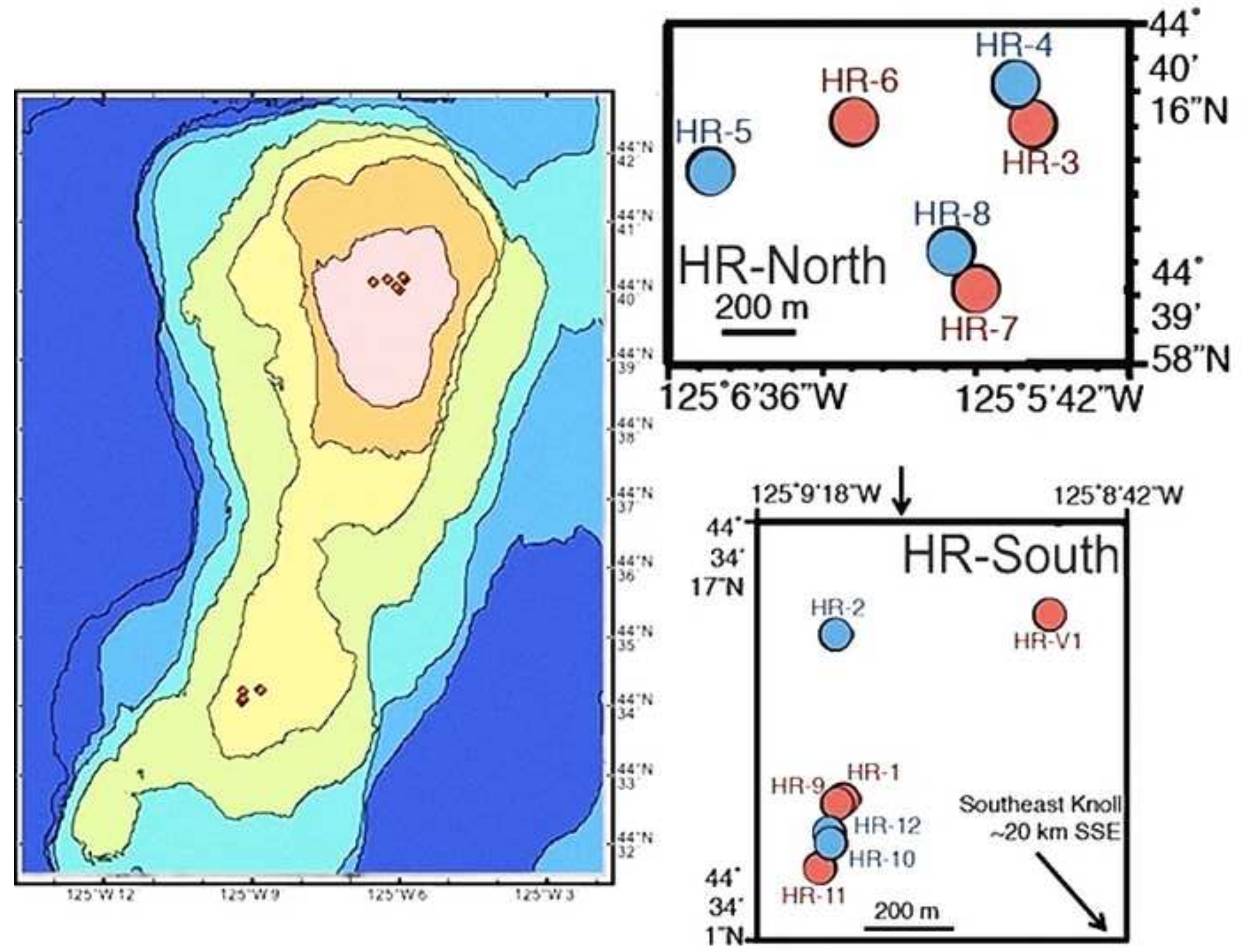
A.

B.

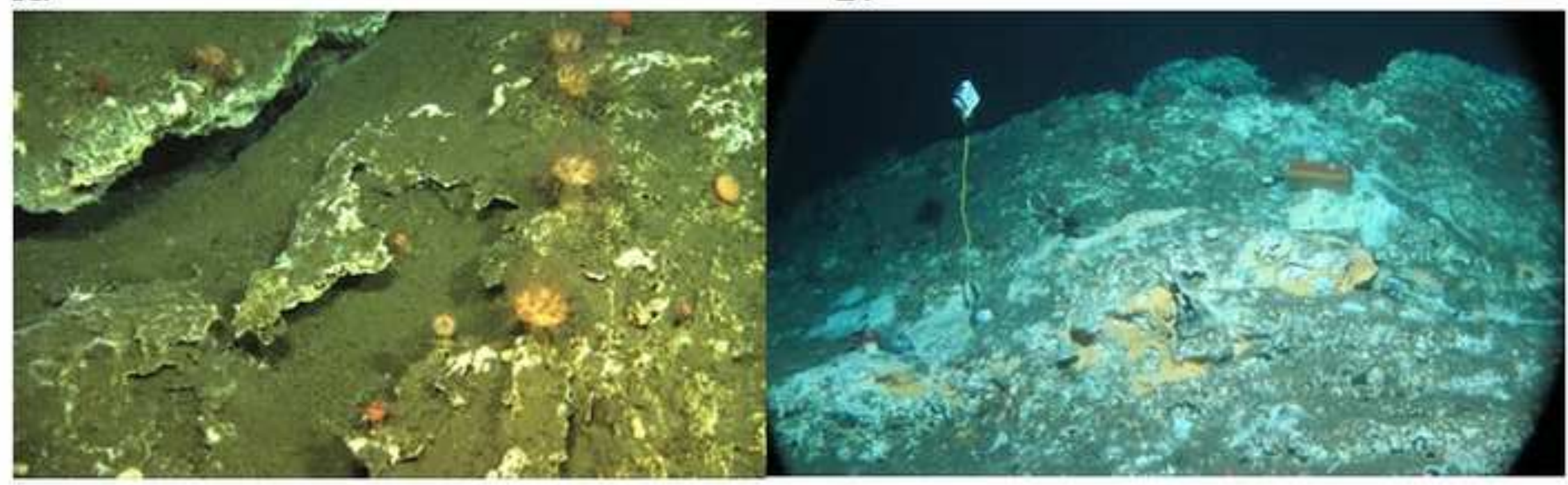

C.

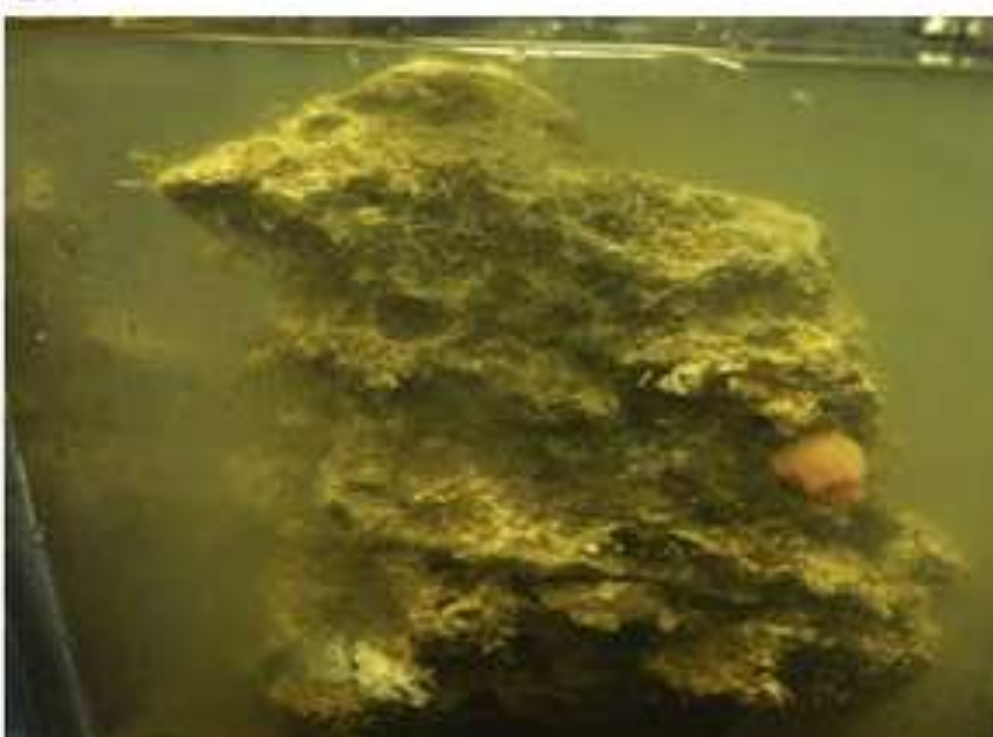

D.
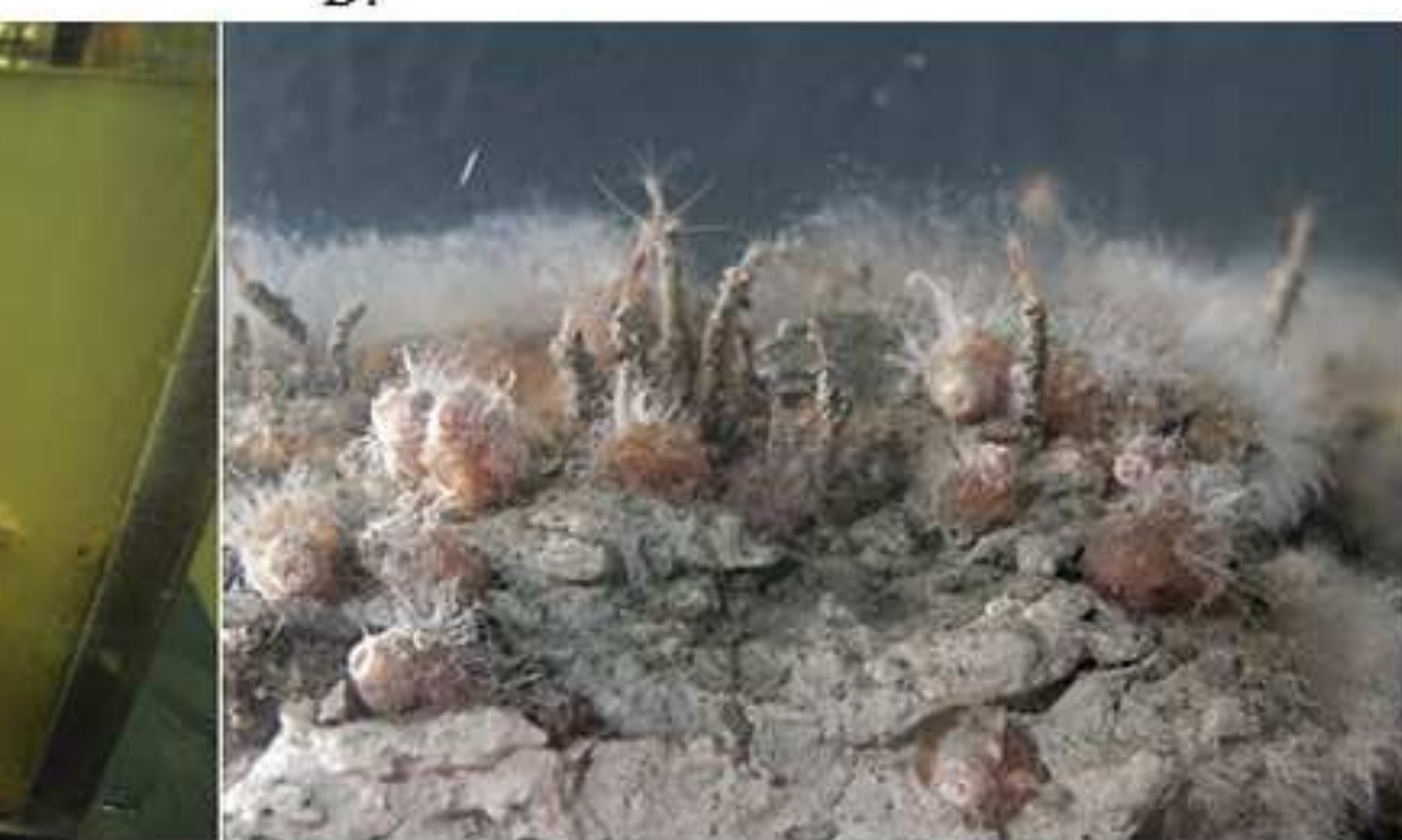


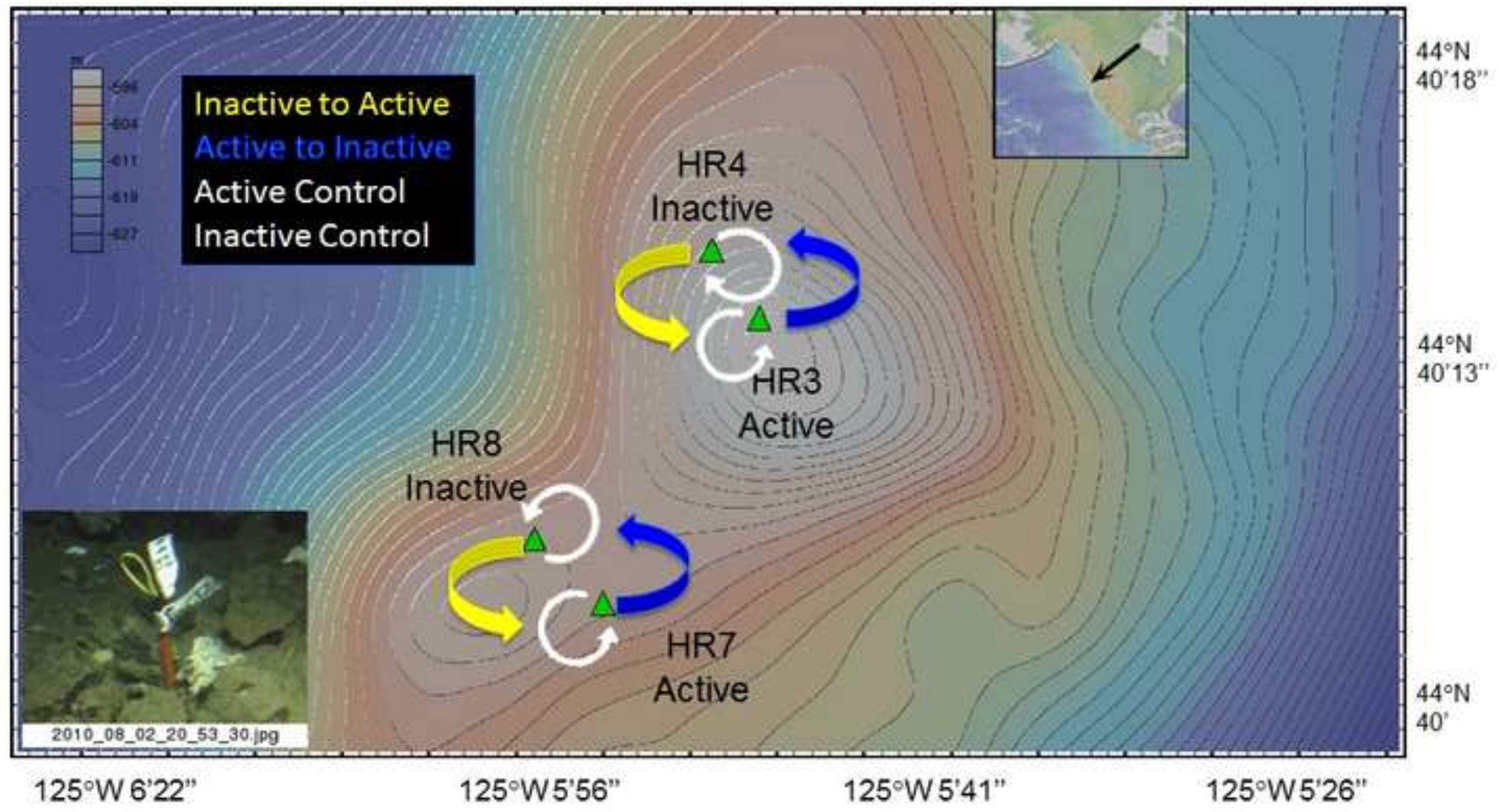




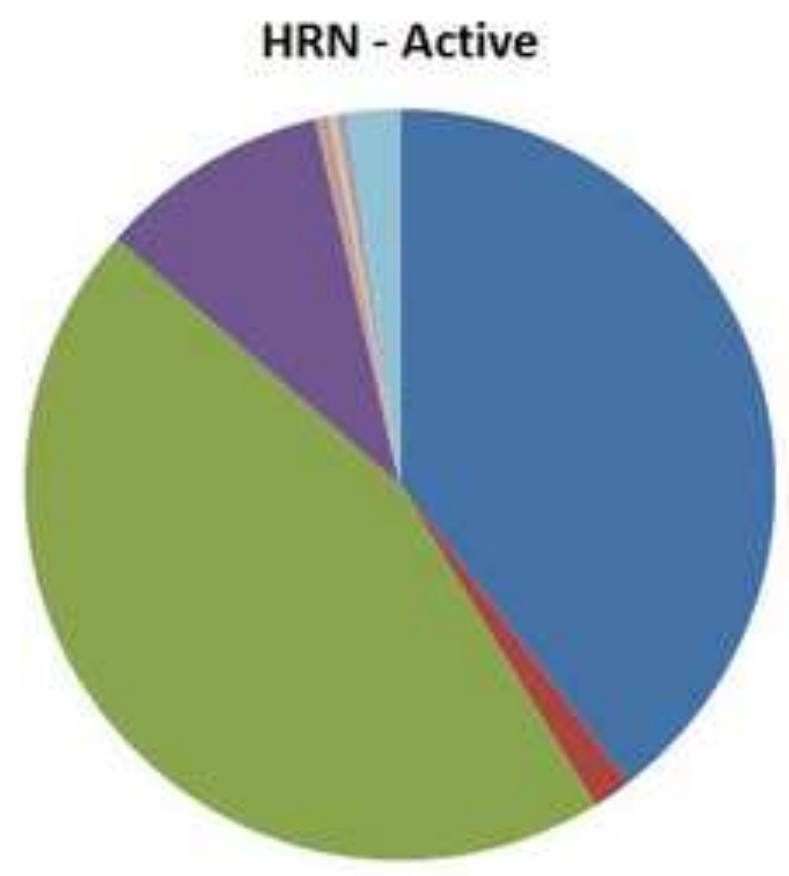

HRS - Active

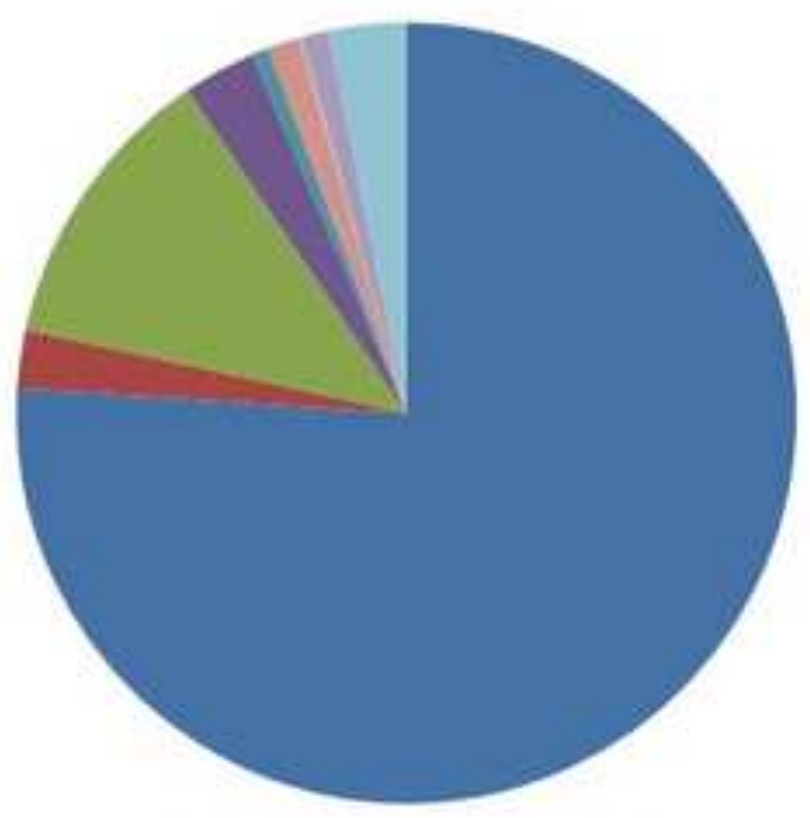

E Annelida $\quad$ Limpet

- Crustacea

= Snail w Other molluscs
HRN - Inactive

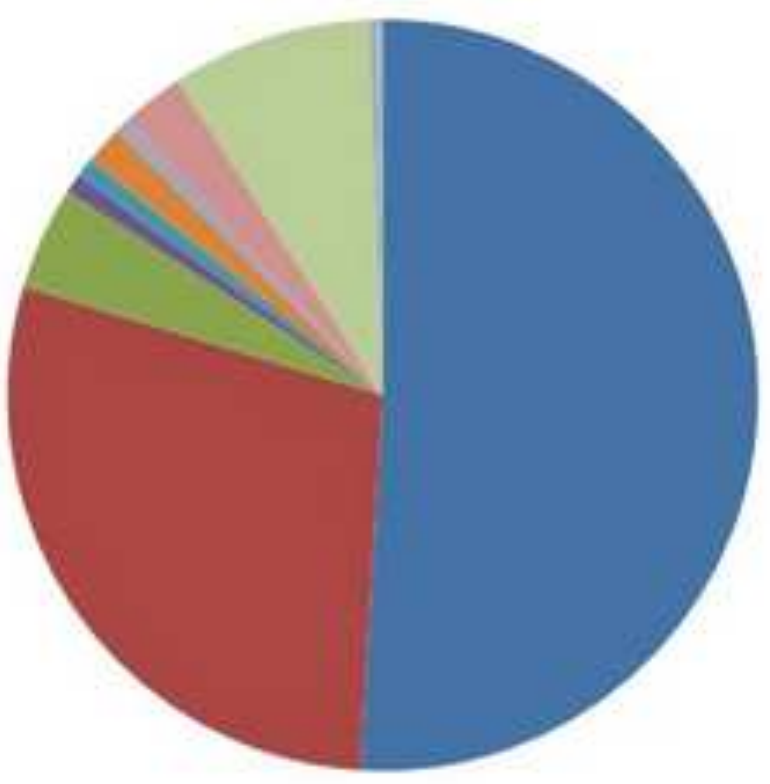

HRS - Inactive

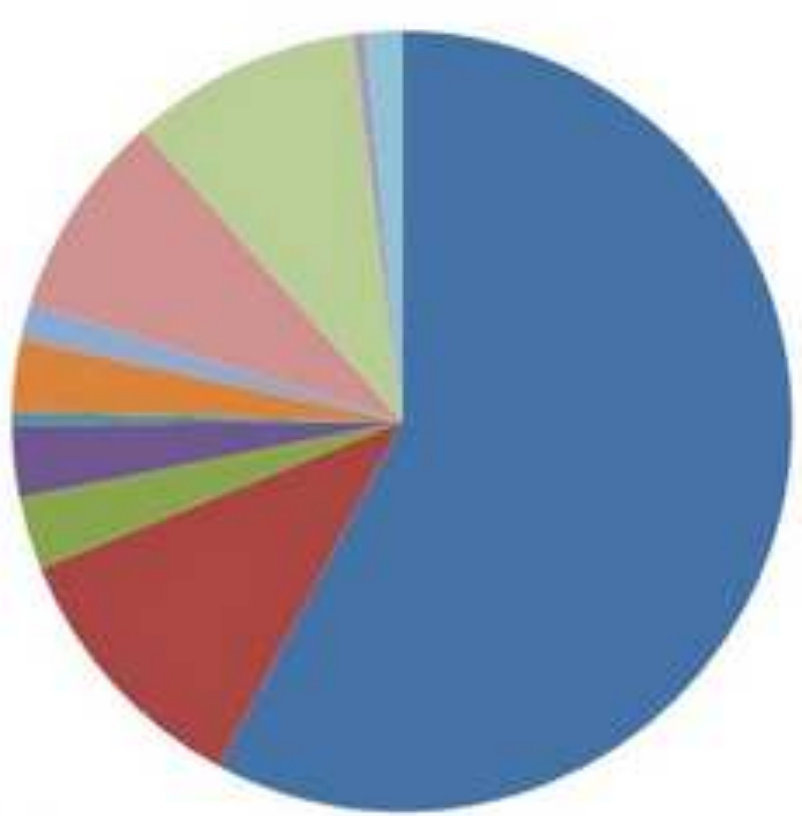

늘 Chiton

쁠 Porifera

in Echinodermata $=$ Other macrofauna

Enidaria 


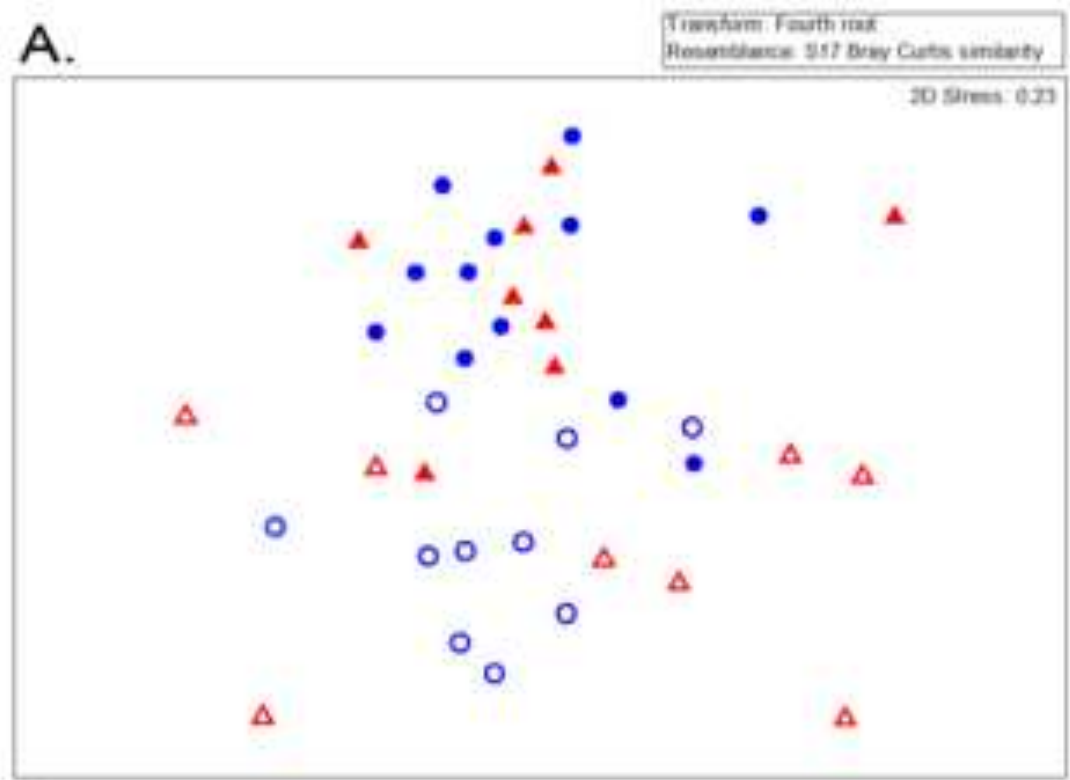

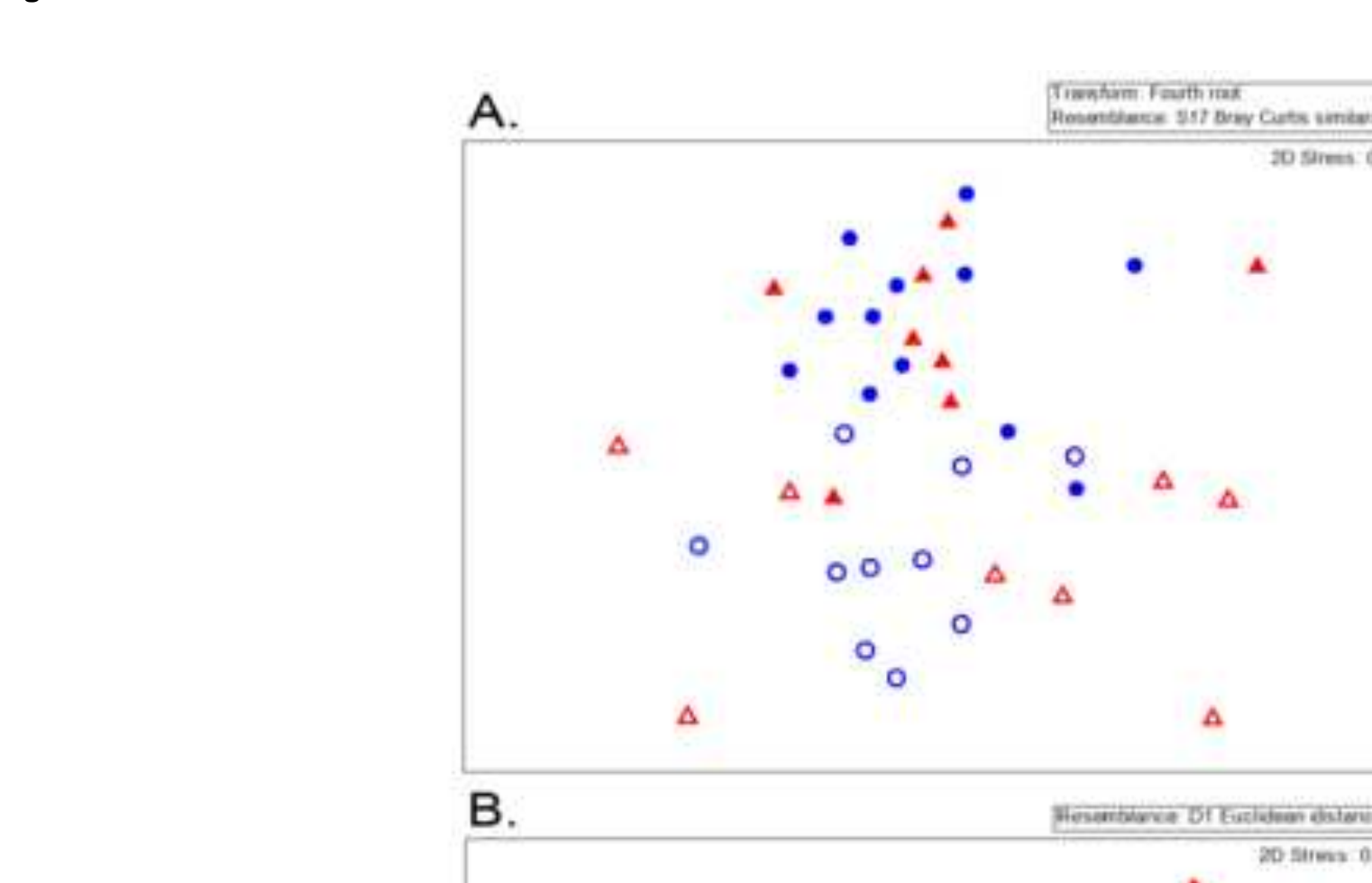

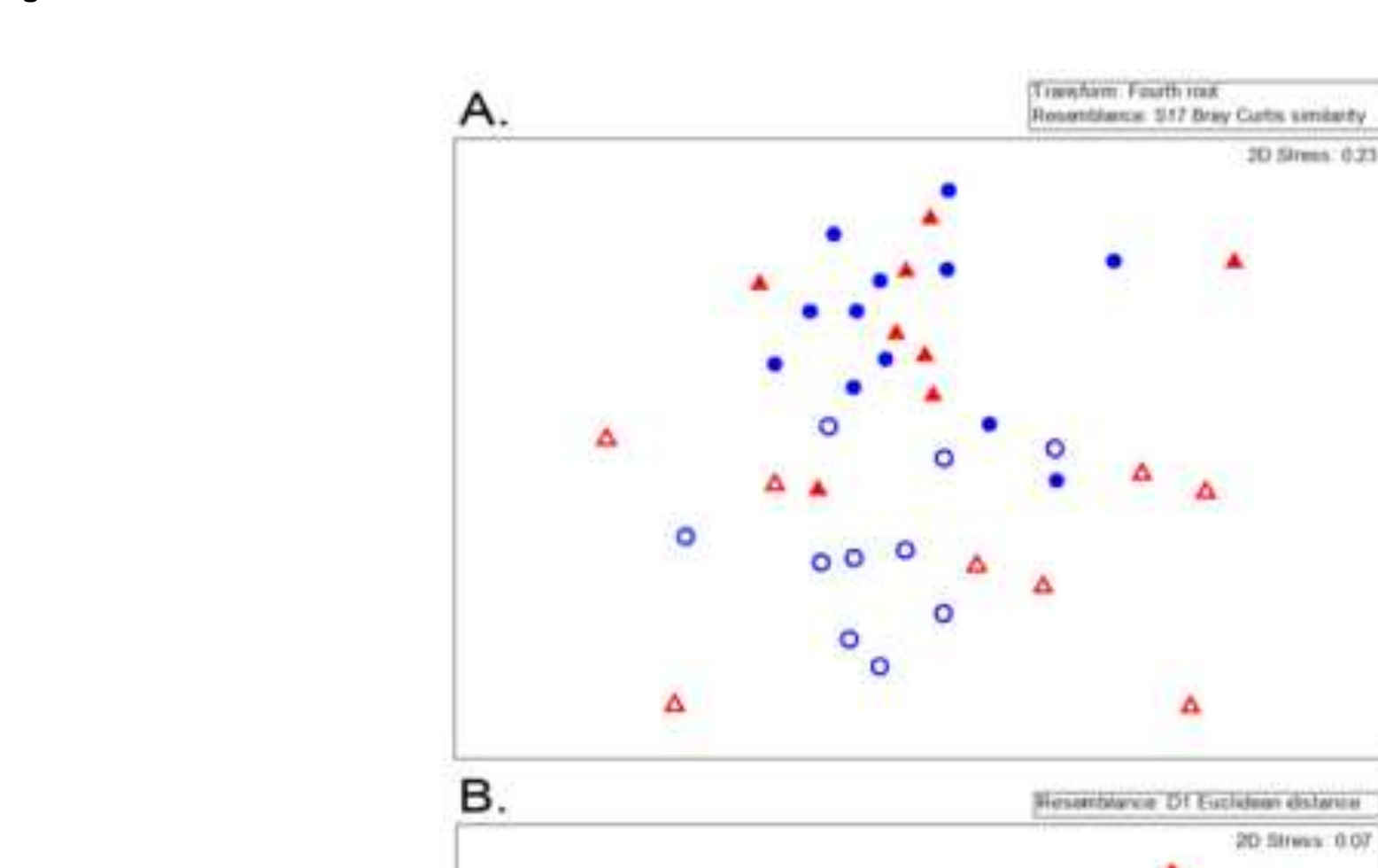

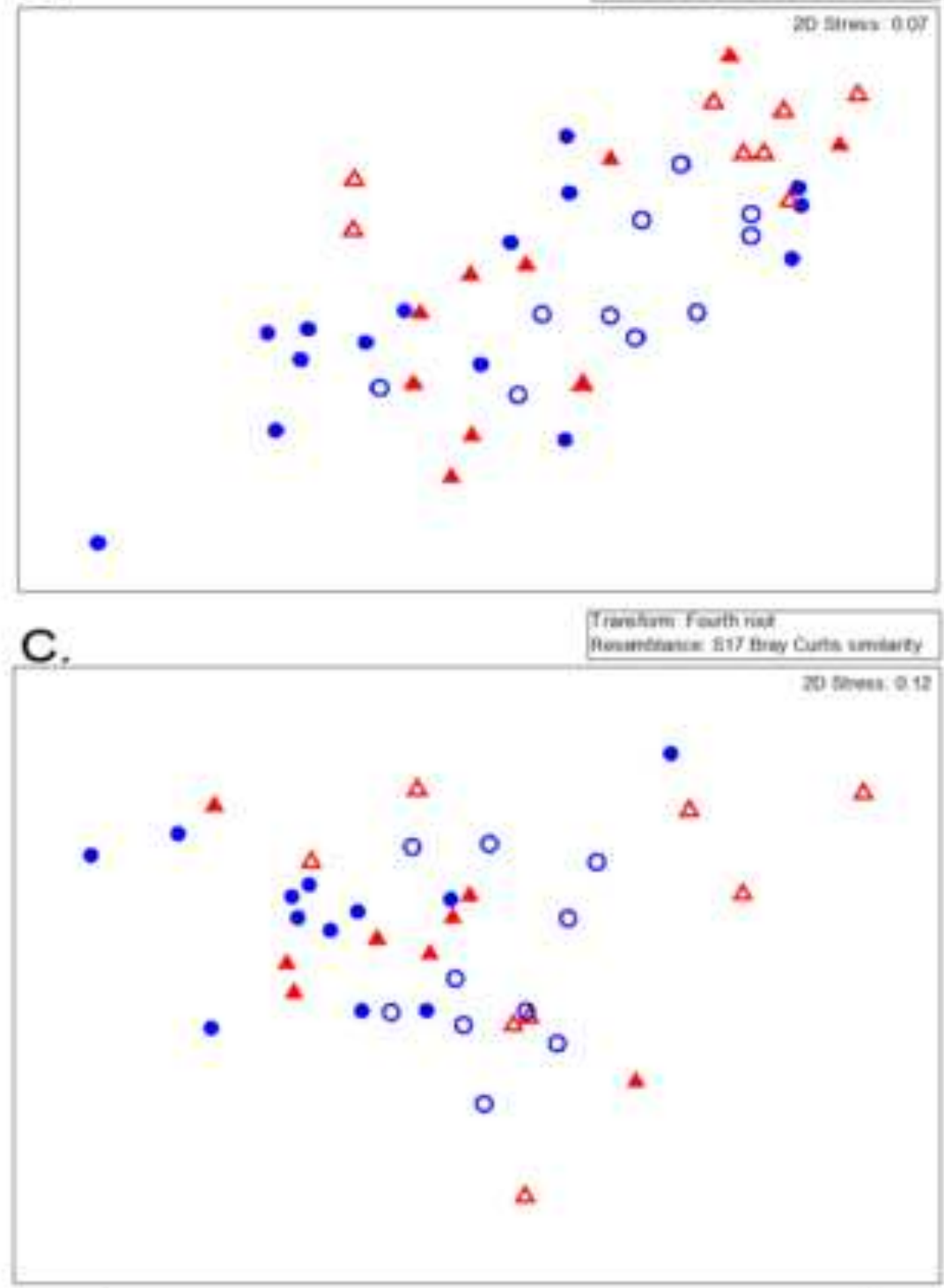

- HR-N_Active $\triangle$ HR-S_Active

O HR-N_Inactive $\triangle \mathrm{HR}$-S_Inactive

Figure 5

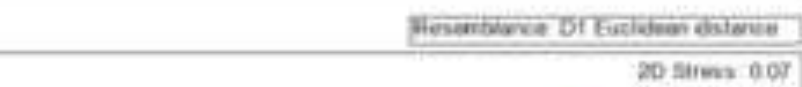

Trabiem farth net

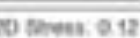

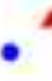

$\because$

$\circ$

o 

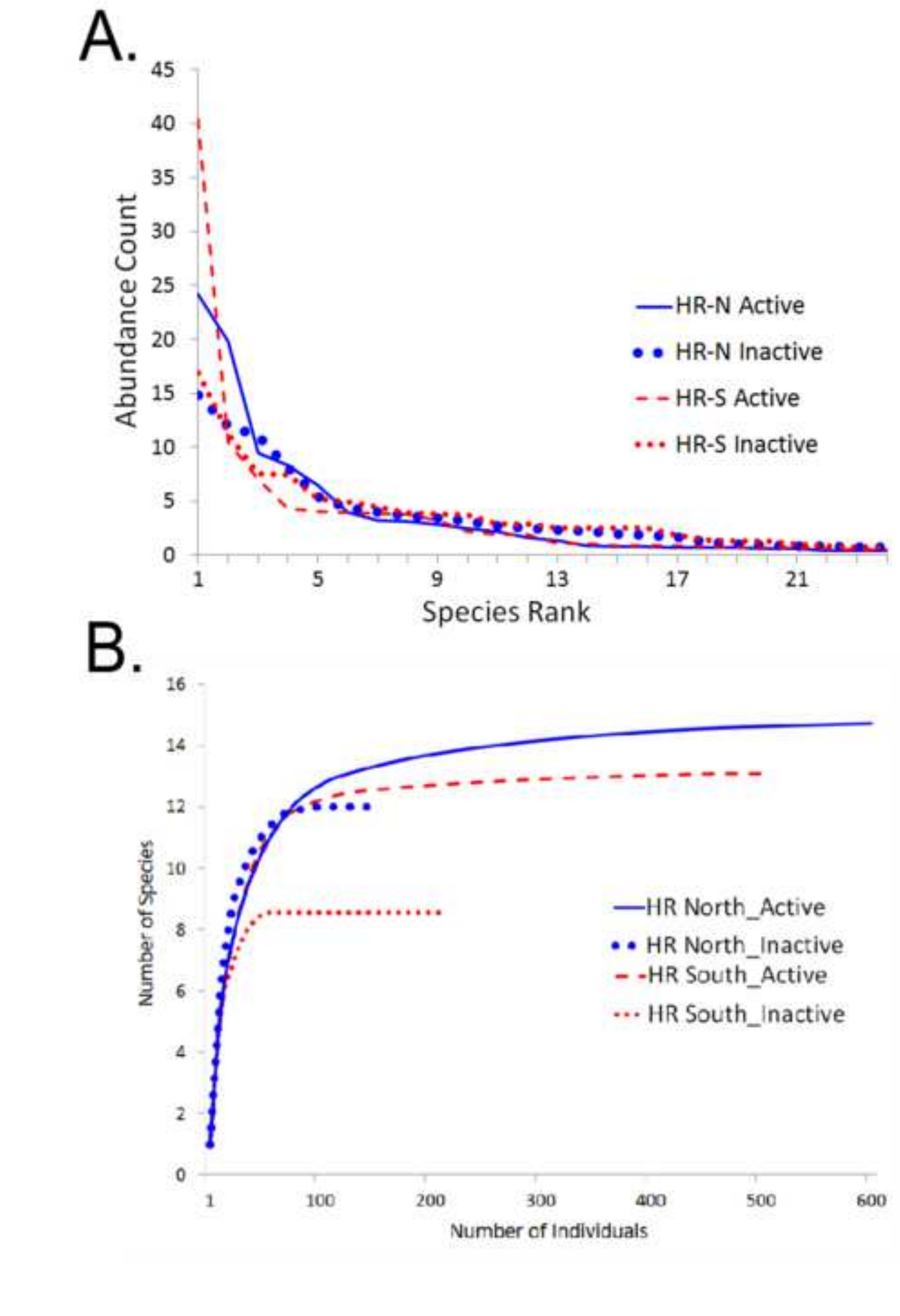

Figure 6

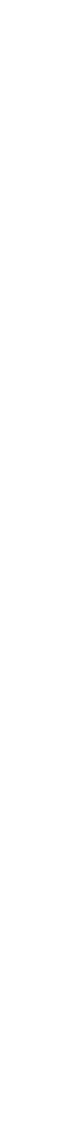
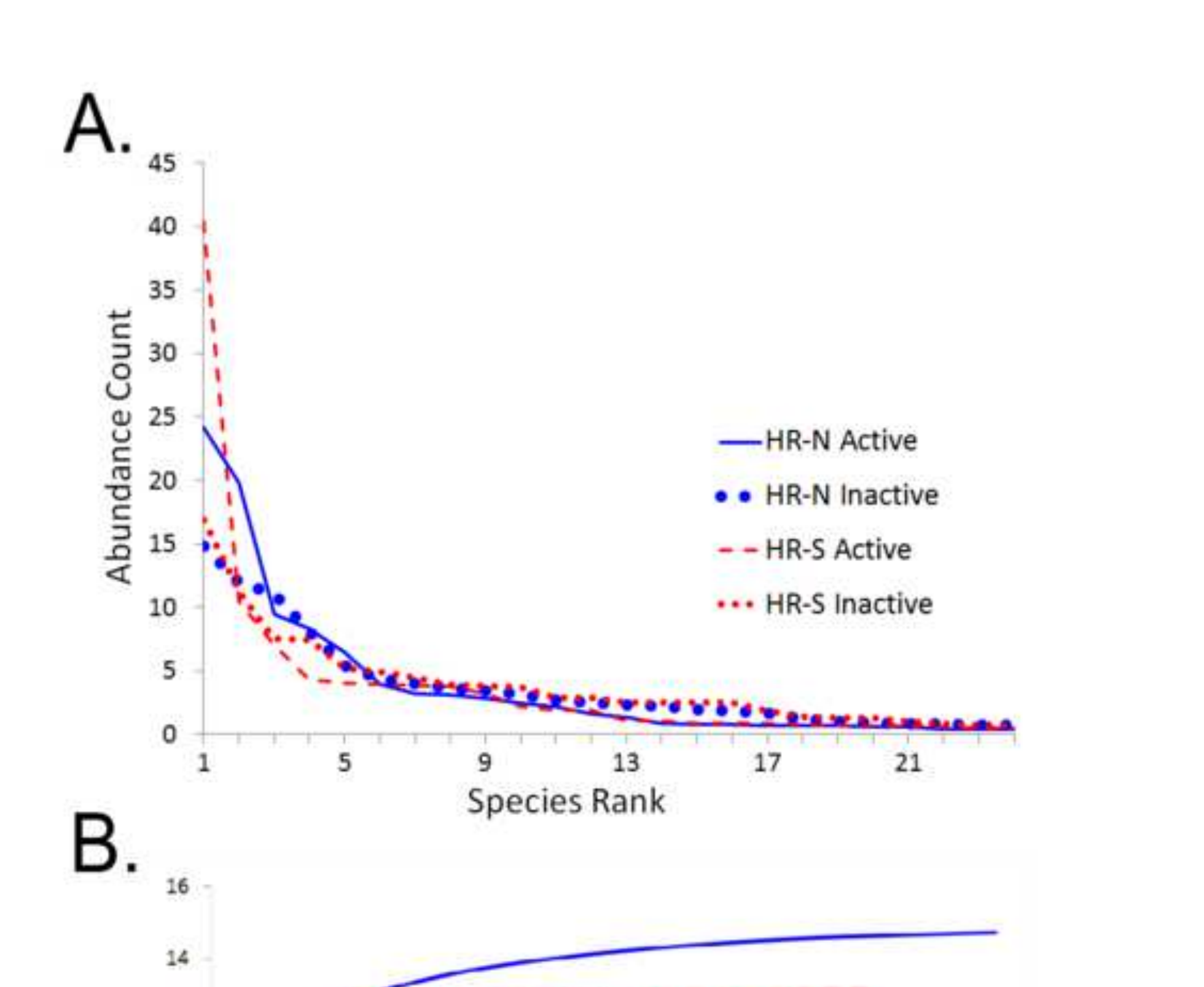

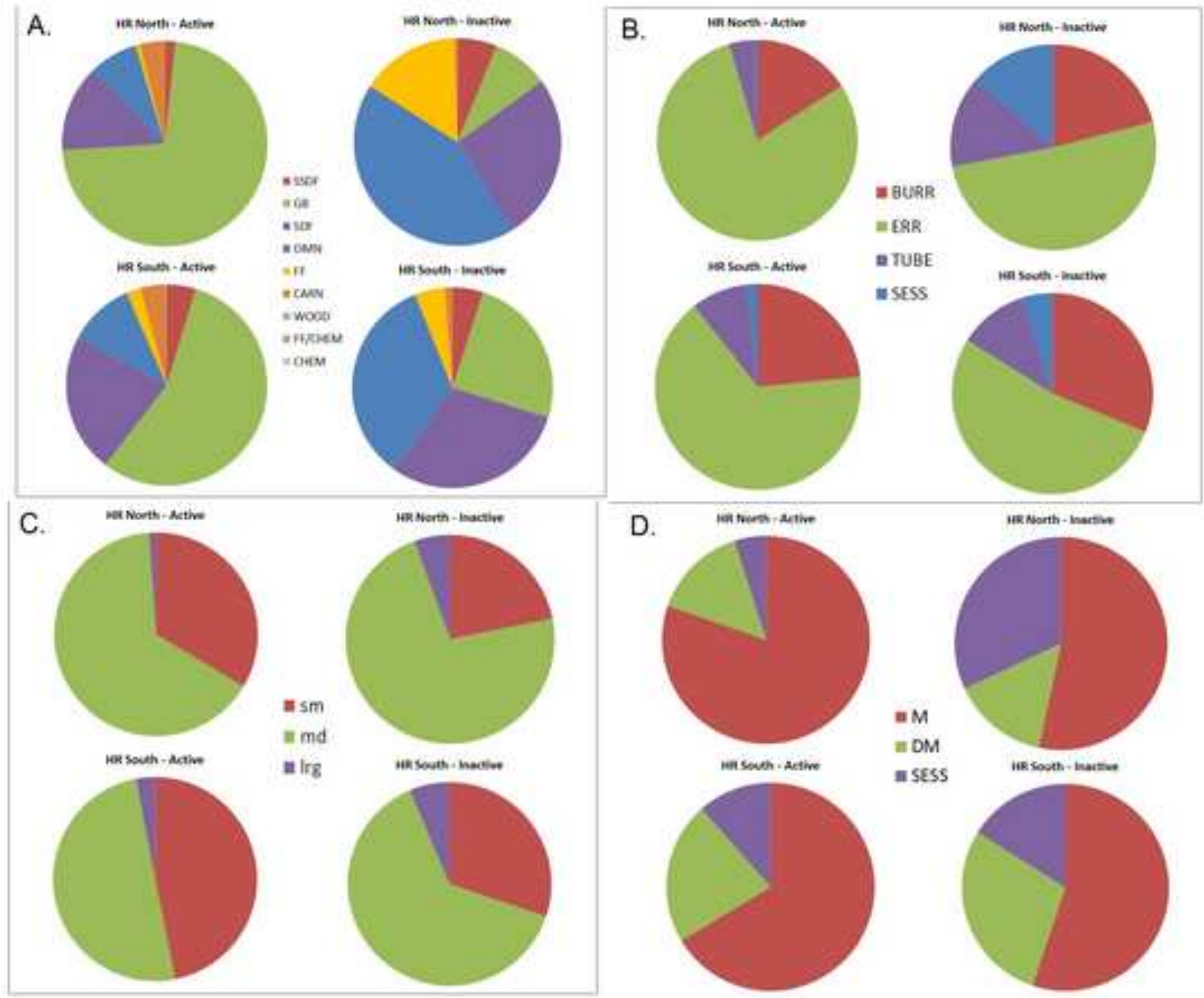

D.

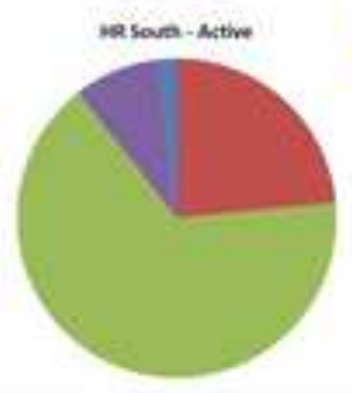

les South-artive
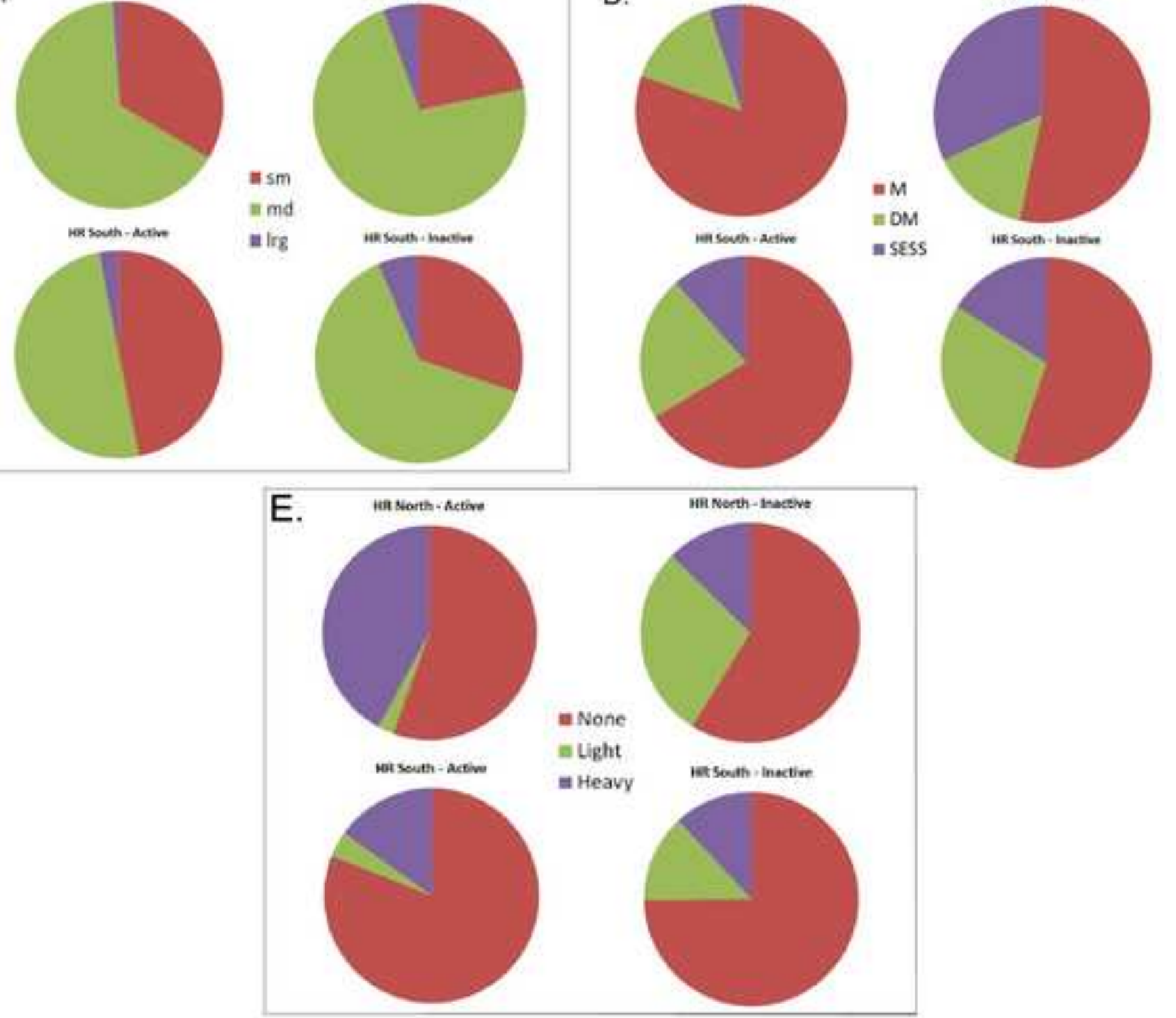

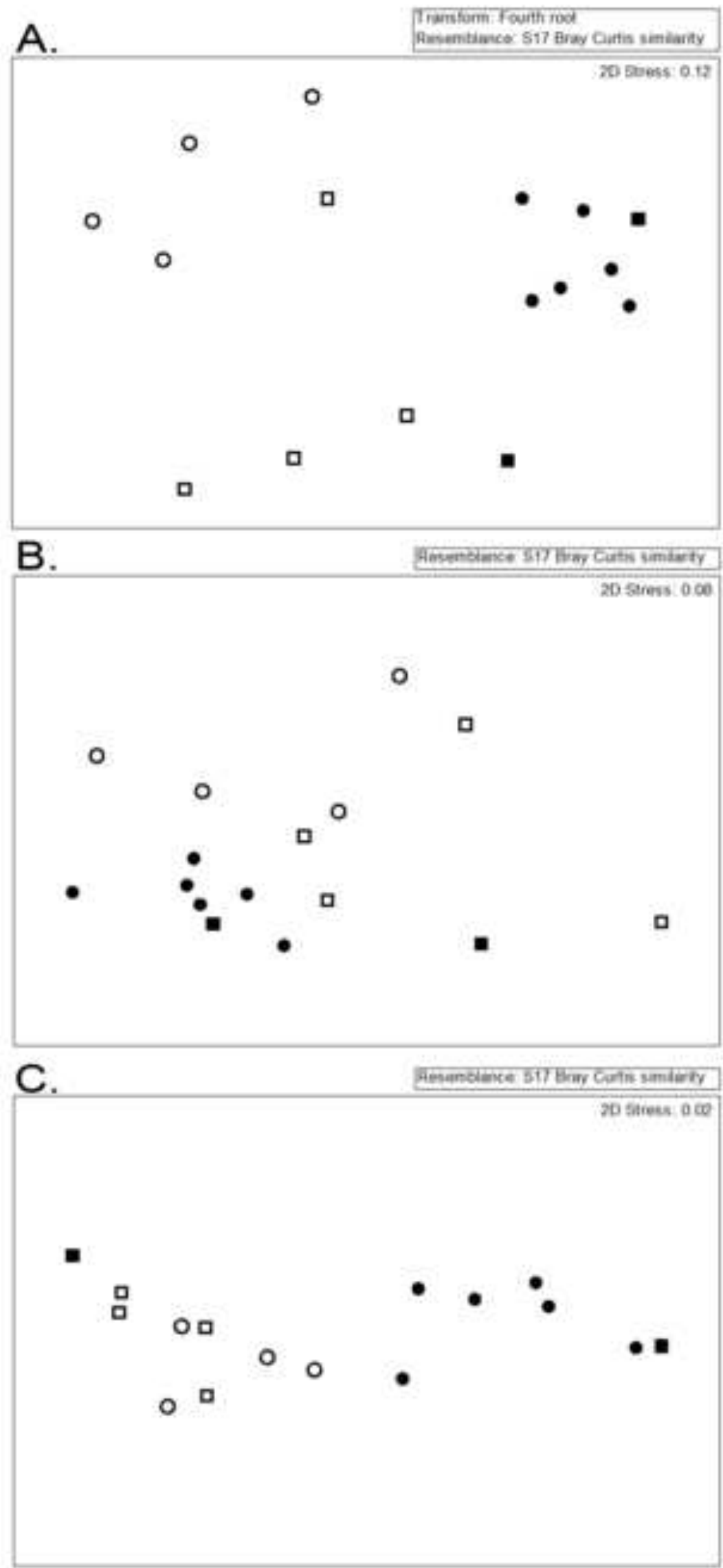

Active Control

- Inactive to Active Transplant $\square$ Active to Inactive Transplant 
A.

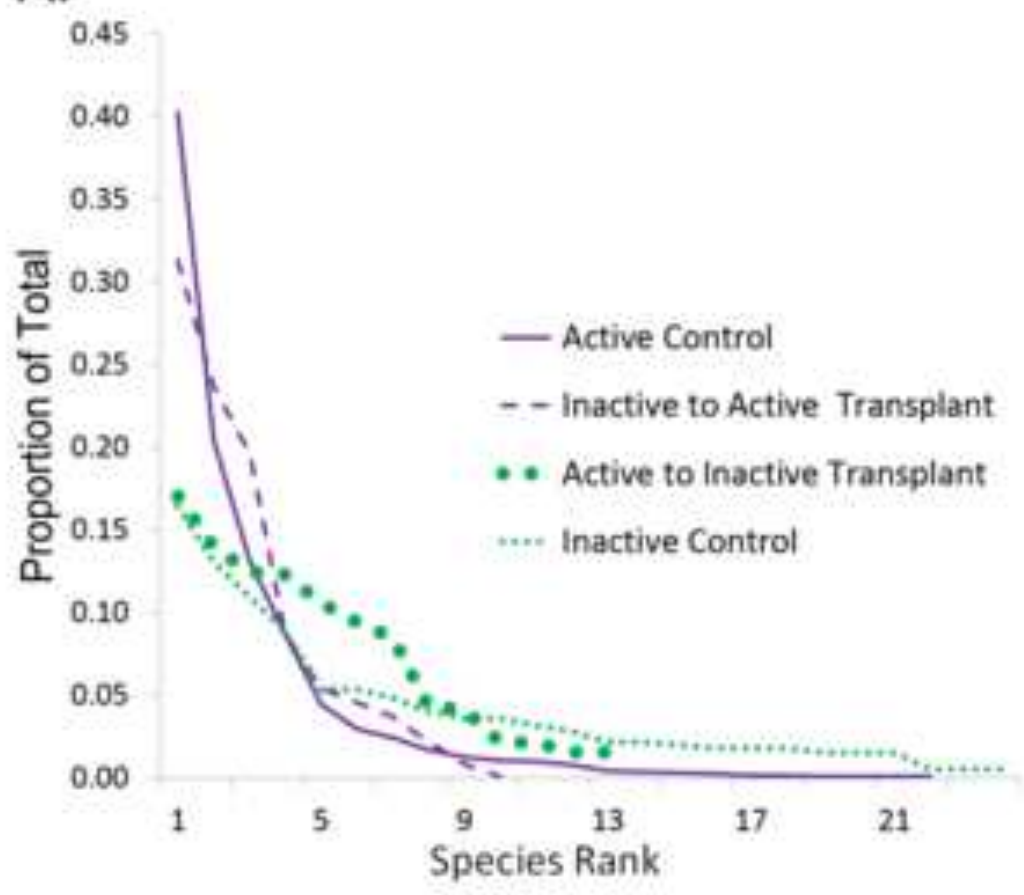

B.

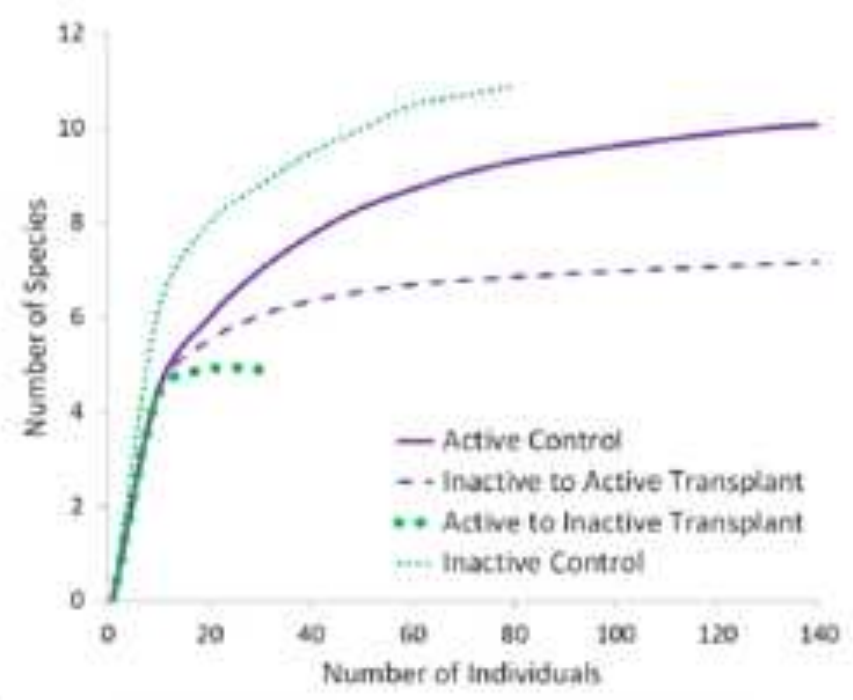

C.

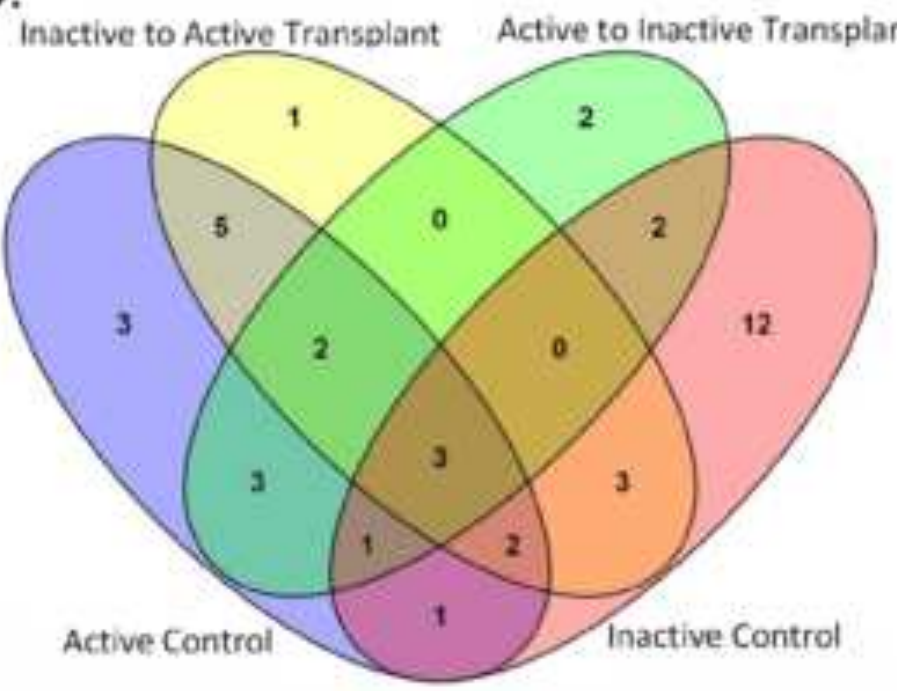




\section{Figure 10}
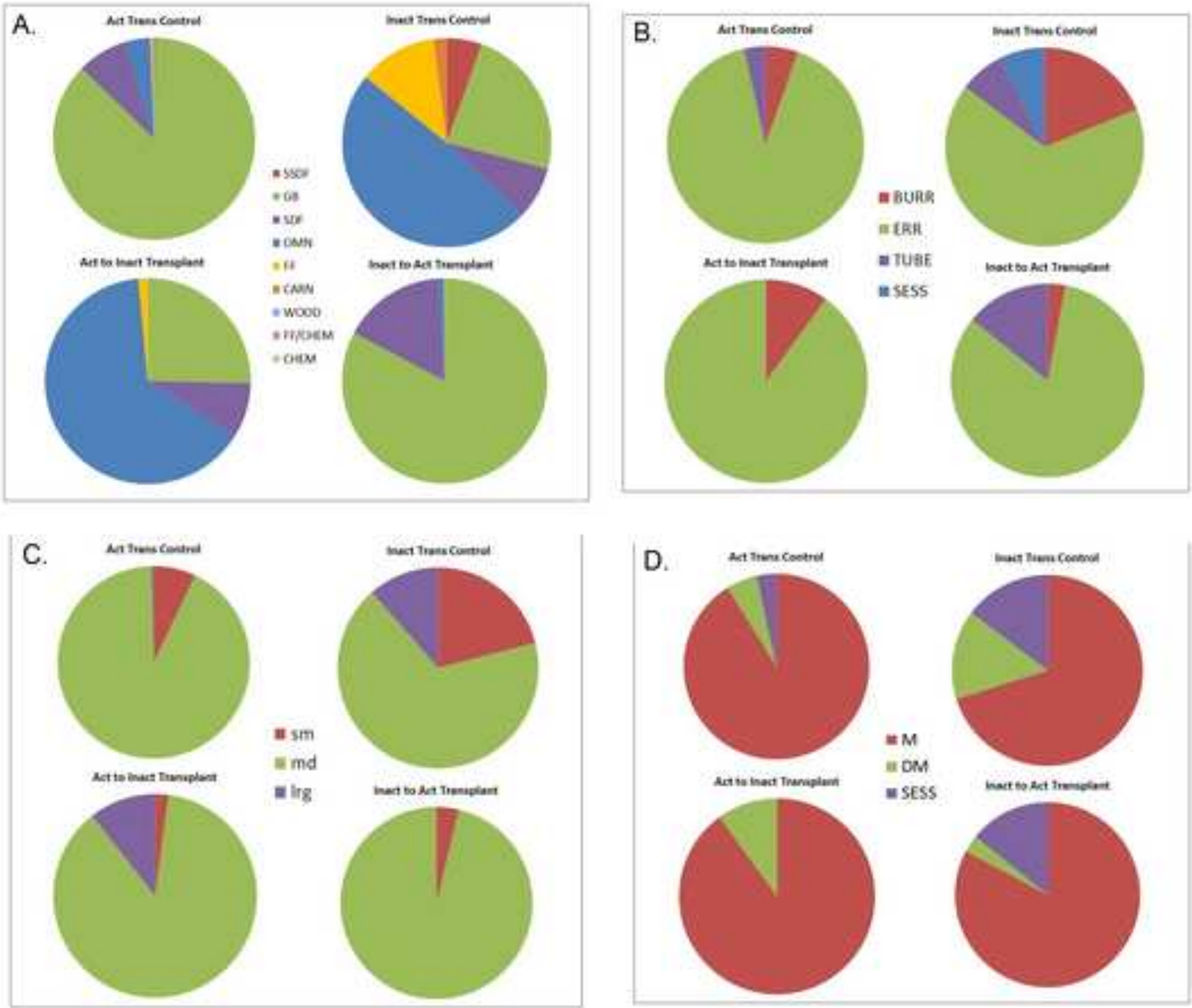

E.
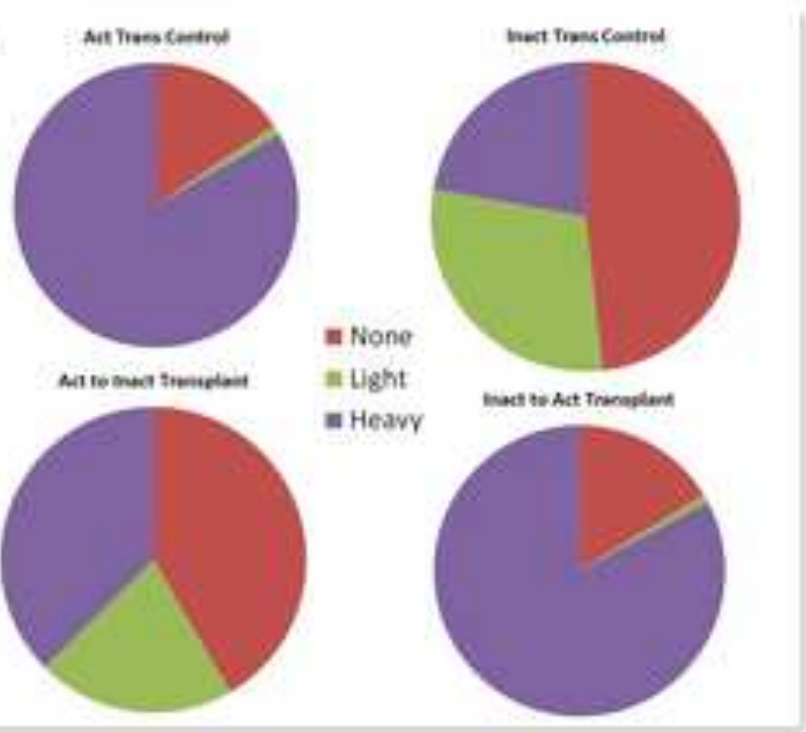


\begin{tabular}{|c|c|c|c|c|c|c|c|}
\hline Location & $\begin{array}{c}\text { Water } \\
\text { Depth (m) }\end{array}$ & $\begin{array}{c}\text { ALVIN } \\
\text { DIVE }\end{array}$ & $\begin{array}{l}\text { Dates } \\
(2010)\end{array}$ & $\begin{array}{l}\text { Station } \\
\text { Marker }\end{array}$ & $\begin{array}{l}\text { Seepage } \\
\text { Activity }\end{array}$ & $\begin{array}{c}\text { Latitude } \\
\qquad(\mathbf{o N})\end{array}$ & $\begin{array}{c}\text { Longitude } \\
(\mathbf{o W})\end{array}$ \\
\hline \multicolumn{8}{|l|}{ Background Rocks } \\
\hline HR South & 774 & 4629 & Aug. 1 & HR-1 & Active & $4434.111 \mathrm{~N}$ & $1259.159 \mathrm{~W}$ \\
\hline HR South & 810 & 4629 & Aug. 1 & HR-2 & Inactive & $4434.217 \mathrm{~N}$ & $1259.095 \mathrm{~W}$ \\
\hline HR North & 587 & 4630 & Aug. 2 & HR-3 & Active & $4440.172 \mathrm{~N}$ & $1255.887 \mathrm{~W}$ \\
\hline HR North & 595 & 4630 & Aug. 2 & HR-4 & Inactive & $4440.2071 \mathrm{~N}$ & $1255.921 \mathrm{~W}$ \\
\hline HR North & 618 & 4631 & Aug. 3 & HR-5 & Inactive & $4440.174 \mathrm{~N}$ & $1256.236 \mathrm{~W}$ \\
\hline HR North & 615 & 4631 & Aug. 3 & HR-6 & Active & $4440.131 \mathrm{~N}$ & $1256.517 \mathrm{~W}$ \\
\hline HR North & 602 & 4632 & Aug. 4 & HR-7 & Active & $4440.027 \mathrm{~N}$ & $1256.000 \mathrm{~W}$ \\
\hline HR North & 602 & 4632 & Aug. 4 & HR-8 & Inactive & $4440.060 \mathrm{~N}$ & $1256.049 \mathrm{~W}$ \\
\hline HR South & 775 & 4635 & Aug. 7 & HR-9 & Active & $4434.108 \mathrm{~N}$ & $1259.169 \mathrm{~W}$ \\
\hline HR South & 788 & 4635 & Aug. 7 & HR-10 & Inactive & $4434.089 \mathrm{~N}$ & $1259.182 \mathrm{~W}$ \\
\hline HR South & 800 & 4636 & Aug. 8 & HR-11 & Active & $4434.066 \mathrm{~N}$ & $1259.197 \mathrm{~W}$ \\
\hline HR South & 792 & 4636 & Aug. 8 & HR-12 & Inactive & $4434.083 \mathrm{~W}$ & $1259.181 \mathrm{~W}$ \\
\hline $\begin{array}{c}\text { Transplant } \\
\text { Experiments (HR } \\
\text { North) }\end{array}$ & & & $\begin{array}{c}\text { Deployme } \\
\text { nt Date }\end{array}$ & & & & \\
\hline Inactive Control 1 & 595 & 4630 & Aug. 2 & HR-4 & Inactive & $4440.20829 \mathrm{~N}$ & $255.91588 \mathrm{~W}$ \\
\hline Inactive Control 2 & 595 & 4630 & Aug. 2 & HR-4 & Inactive & $4540.20829 \mathrm{~N}$ & $265.91588 \mathrm{~W}$ \\
\hline Inactive Control 3 & 603 & 4634 & Aug. 6 & HR-8 & Inactive & $4440.06305 \mathrm{~N}$ & $256.05028 \mathrm{~W}$ \\
\hline Inactive Control 4 & 603 & 4634 & Aug. 6 & HR-8 & Inactive & $4440.06305 \mathrm{~N}$ & $256.05028 \mathrm{~W}$ \\
\hline tive to Inactive-Transplas & 619 & 4631 & Aug. 3 & HR-4 & Inactive & $4440.16780 \mathrm{~N}$ & $256.22848 \mathrm{~W}$ \\
\hline tive to Inactive Transplar & 619 & 4631 & Aug. 3 & HR-4 & Inactive & $4440.16780 \mathrm{~N}$ & $256.22848 \mathrm{~W}$ \\
\hline tive to Inactive-Transplas & 602 & 4632 & Aug. 4 & HR-8 & Inactive & $4440.05981 \mathrm{~N}$ & $256.04877 \mathrm{~W}$ \\
\hline tive to Inactive-Transplas & 602 & 4632 & Aug. 4 & HR-8 & Inactive & $4440.05981 \mathrm{~N}$ & $256.04877 \mathrm{~W}$ \\
\hline ctive to Active Transplan & 587 & 4630 & Aug. 2 & HR-3 & Active & $4440.16888 \mathrm{~N}$ & $255.88417 \mathrm{~W}$ \\
\hline ctive to Active Transplar & 587 & 4630 & Aug. 2 & HR-3 & Active & $4440.16888 \mathrm{~N}$ & $255.88417 \mathrm{~W}$ \\
\hline ctive to Active Transplar & 602 & 4634 & Aug. 6 & HR-7 & Active & $4440.02903 \mathrm{~N}$ & $256.00120 \mathrm{~W}$ \\
\hline etive to Active Transplan & 602 & 4634 & Aug. 6 & HR-7 & Active & $4440.02903 \mathrm{~N}$ & $256.00120 \mathrm{~W}$ \\
\hline Active Control 1 & 587 & 4631 & Aug. 3 & HR-3 & Active & $4440.17212 \mathrm{~N}$ & $255.88945 \mathrm{~W}$ \\
\hline Active Control 2 & 587 & 4631 & Aug. 3 & HR-3 & Active & $4440.17212 \mathrm{~N}$ & $255.88945 \mathrm{~W}$ \\
\hline Active Control 3 & 602 & 4632 & Aug. 4 & HR-7 & Active & $4440.02687 \mathrm{~N}$ & $255.99969 \mathrm{~W}$ \\
\hline Active Control 4 & 602 & 4632 & Aug. 4 & HR-7 & Active & $4440.02687 \mathrm{~N}$ & $255.99969 \mathrm{~W}$ \\
\hline
\end{tabular}

\footnotetext{
* failure to recover
} 


\begin{tabular}{|c|c|c|c|c|c|c|c|}
\hline Location & Site & $\begin{array}{c}\text { Number of } \\
\text { Backgroun } \\
\text { d }\end{array}$ & $\begin{array}{c}\text { Number } \\
\text { with surface } \\
\text { area } \\
\text { quantified }\end{array}$ & $\begin{array}{c}\text { Transplant } \\
\text { Exp. Active } \\
\text { Control } \\
\end{array}$ & $\begin{array}{l}\text { Transplant } \\
\text { Exp. } \\
\text { Inactive to } \\
\text { Active } \\
\end{array}$ & $\begin{array}{c}\text { Transplant } \\
\text { Expt. } \\
\text { Inactive } \\
\text { Control } \\
\end{array}$ & $\begin{array}{l}\text { Transplant } \\
\text { Expt. Active } \\
\text { to Inactive }\end{array}$ \\
\hline \multirow[b]{3}{*}{ HR North } & HR-3 & 8 & 7 & 3 & 1 & & \\
\hline & \begin{tabular}{|l|} 
HR-6 \\
\end{tabular} & 2 & 2 & & & & \\
\hline & HR-7 & 6 & 4 & 3 & $0(1)$ & & \\
\hline \multirow[b]{3}{*}{ HR South } & HR-1 & 4 & 3 & & & & \\
\hline & \begin{tabular}{|l|} 
HR-9 \\
\end{tabular} & 3 & 3 & & & & \\
\hline & HR-11 & 3 & 2 & & & & \\
\hline \multicolumn{2}{|c|}{ Active Total } & 26 & 21 & 6 & 2 & & \\
\hline \multirow[b]{3}{*}{ HR North } & HR-4 & 4 & 3 & & & 2 & 2 \\
\hline & \begin{tabular}{|l|} 
HR-5 \\
\end{tabular} & 3 & 3 & & & & \\
\hline & HR-8 & 3 & 3 & & & 2 & 2 \\
\hline \multirow[b]{3}{*}{ HR South } & HR-2 & 3 & 3 & & & & \\
\hline & HR-10 & 2 & 2 & & & & \\
\hline & HR-12 & 4 & 3 & & & & \\
\hline \multicolumn{2}{|c|}{ Inactive Total } & 19 & 17 & & & 4 & 4 \\
\hline
\end{tabular}


A. Summary Statistics

\begin{tabular}{|c|c|c|c|c|}
\hline Activity & Active & Inactive & Active & Inactive \\
\hline Location & HR-N & HR-N & HR-S & HR-S \\
\hline $\begin{array}{l}\text { Density per } 200 \\
\mathrm{~cm}^{2}(\text { Mean/SE) }\end{array}$ & $61.5(31.0)$ & $12.7(7.0)$ & $29.8(14.7)$ & $10.9(8.7)$ \\
\hline \multicolumn{5}{|l|}{\begin{tabular}{|l|} 
Diversity (mean) \\
\end{tabular}} \\
\hline \begin{tabular}{|l|l}
$\mathbf{S}$ \\
\end{tabular} & 14.73 & 12.00 & 13.10 & 8.56 \\
\hline \begin{tabular}{|l|}
$J^{\prime}$ \\
\end{tabular} & 0.76 & 0.85 & 0.77 & 0.92 \\
\hline$\overline{E S(10)}$ & 5.43 & 6.10 & 5.24 & 5.42 \\
\hline $\mathrm{H}^{\prime}(\operatorname{loge})$ & 1.95 & 2.05 & 1.86 & 1.76 \\
\hline $\mathrm{H}^{\prime}(\log 10)$ & 0.85 & 0.89 & 0.81 & 0.76 \\
\hline Rank 1 Dominan & $24.15 \%$ & $14.81 \%$ & $40.47 \%$ & $16.88 \%$ \\
\hline
\end{tabular}

B. Top 10 Taxa

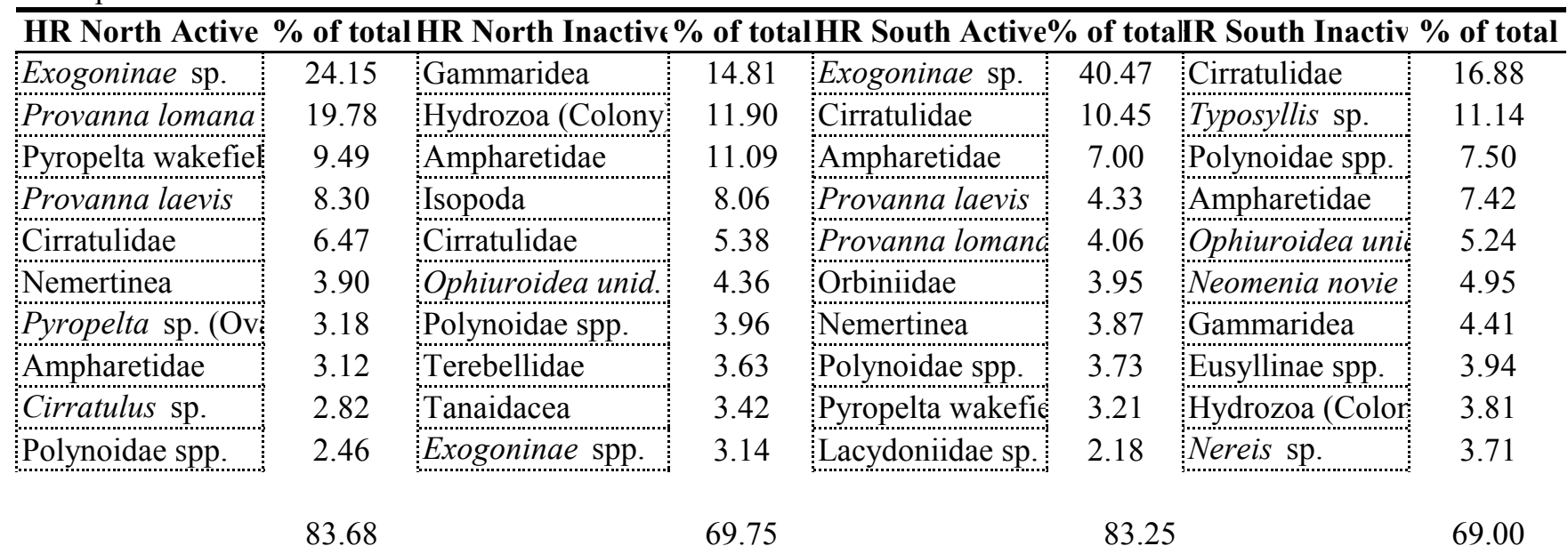




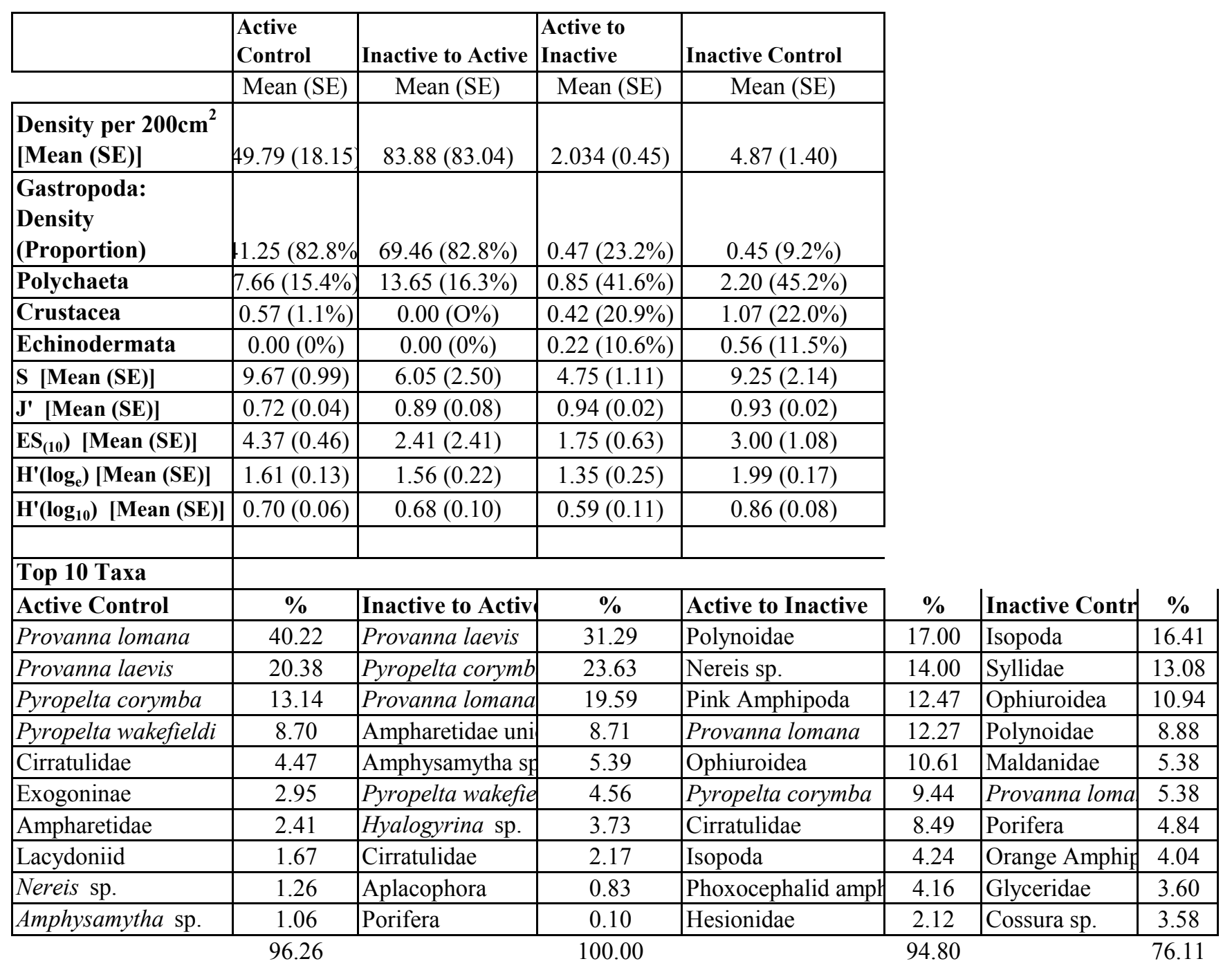


A. Composition Active Contro nactive to ActiviActive to InactiveInactive Control $\begin{array}{lllll}\text { Active Control } & 53.34 & 59.65 & 80.49 & 92.3\end{array}$ Inactive to Active

0.143

20.79

84.16

90.9

Active to Inactive

0.005

0.067

29.36

79.5

Inactive Contro

$\mathbf{0 . 0 0 5} \quad 0.067$

0.029

33.37

B. Traits (Species) Active Contro nactive to ActiviActive to InactiveInactive Control Active Control 84.92

19.36

32.15

22.5

Inactive to Active

0.143

75.54

32.76

23.82

Active to Inactive

0.01

0.4

70.02

32.58

Inactive Control

0.005

0.267

0.257

77.44

C. (Individuals) Active Contro nactive to ActiviActive to InactiveInactive Control Active Control 77.86

36.73

48.85

36.21

Inactive to Active

0.071

38.6

48.73

40.38

Active to Inactive

0.005

0.133

70.33

33.76

Inactive Control

0.005

0.067

0.371

73.93 